\title{
An assessment of the vertical diffusive flux of iron and other nutrients to the surface waters of the subpolar North Atlantic Ocean
}

\author{
S. C. Painter ${ }^{1}$, S. A. Henson ${ }^{1}$, A. Forryan ${ }^{2}$, S. Steigenberger ${ }^{2}$, J. Klar ${ }^{2}$, M. C. Stinchcombe ${ }^{1}$, N. Rogan ${ }^{3}$, A. R. Baker ${ }^{4}$, \\ E. P. Achterberg ${ }^{2, *}$, and C. M. Moore ${ }^{2}$ \\ ${ }^{1}$ National Oceanography Centre, European Way, Southampton, SO14 3ZH, UK \\ ${ }^{2}$ Ocean and Earth Science, National Oceanography Centre Southampton, University of Southampton Waterfront Campus, \\ European Way, Southampton, SO14 3ZH, UK \\ ${ }^{3}$ Department of Earth, Ocean and Ecological Sciences, University of Liverpool, Liverpool, L69 3GP, UK \\ ${ }^{4}$ School of Environmental Sciences, University of East Anglia, Norwich, NR4 7TJ, UK \\ *now at: GEOMAR Helmholtz Centre for Ocean Research Kiel, Wischhofstraße, 1-3, 24148 Kiel, Germany
}

Correspondence to: S. C. Painter (stuart.painter@noc.ac.uk)

Received: 1 November 2013 - Published in Biogeosciences Discuss.: 28 November 2013

Revised: 3 February 2014 - Accepted: 11 February 2014 - Published: 16 April 2014

\begin{abstract}
In this study we report diapycnal diffusive fluxes of dissolved iron $(\mathrm{dFe})$, dissolved aluminium $(\mathrm{dAl})$ and the major macronutrients to the surface waters of the North Atlantic subpolar gyre. Turbulent diffusivities at the base of the summer mixed layer ranged from 0.01 to 0.5 (median $0.07) \mathrm{cm}^{2} \mathrm{~s}^{-1}$ and daily macronutrient fluxes into the surface mixed layer typically represented $<0.5 \%$ of integrated mixed layer inventories, although fluxes were highly variable. Elevated nutrient fluxes of up to $4 \%$ of mixed layer inventories were identified on the Greenland Shelf, where integrated nutrient pools were lowest due to localised shoaling of the mixed layer. Diffusive fluxes of dFe and dAl were typically $<0.1 \%$ of mixed layer inventories but were also highly variable between stations. Approximations of daily phytoplankton nutrient and $\mathrm{Fe}$ uptake indicate that the diffusive flux may at best represent $<10 \%$ of phytoplankton macronutrient uptake, and only $1 \%$ of daily phytoplankton Fe uptake. The daily turbulent diffusive flux of $\mathrm{dFe}$ was comparable in magnitude to coincident estimates of aeolian Fe supply but despite shallower than normal convective mixing in winter 2010 the diffusive supply was 22 and 59 times smaller than the annual convective supply of Fe to the Irminger and Iceland basins respectively. The general picture obtained from this study is one of small magnitude diffusive nutrient and Fe fluxes to the subpolar North Atlantic during the period of annual nutrient minima and indicates that the diffusive supply mechanism is unlikely to alleviate the recently identified
\end{abstract}

presence of seasonal iron limitation within the North Atlantic subpolar gyre; a condition exacerbated by low $\mathrm{dFe}: \mathrm{NO}_{3}^{-}$ratios in subsurface source waters.

\section{Introduction}

In the subpolar North Atlantic, winter convective mixing represents the dominant nutrient supply process (Louanchi and Najjar, 2001). This annual event, which can reach 700-800 m depths or more (Bacon et al., 2003; Pickart et al., 2003; Yashayaev et al., 2007), recharges surface ocean nutrient inventories and subsequently fuels the spring phytoplankton bloom. During the remainder of the year nutrients are resupplied continuously or episodically through additional processes. Such processes include mesoscale and sub-mesoscale physical processes (e.g. eddies and fronts), vertical turbulent diffusion, lateral advection and atmospheric deposition. The episodic nature of most of these processes results in highly variable rates and spatial scales of nutrient resupply and considerable variation in subsequent biological impact.

Surface nutrient concentrations in the subpolar North Atlantic reach an annual minimum in late summer (Holliday et al., 2006; Waniek and Holliday 2006). However, surface $\mathrm{NO}_{3}^{-}$concentrations are not usually drawn down to exhaustion during the summer and in the Irminger and Iceland sub-basins have been shown to remain at concentrations 
of $2-6 \mu \mathrm{mol} \mathrm{L}^{-1}$ (Sambrotto et al., 1993; Sanders et al., 2005; Holliday et al., 2006); concentrations not normally considered low enough to limit primary production $(<$ $0.5 \mu \mathrm{mol} \mathrm{L}^{-1}$; Eppley et al., 1969). The presence of residual surface $\mathrm{NO}_{3}^{-}$concentrations has been commented on previously (e.g. Martin et al., 1993) and was interpreted by Sanders et al. (2005), as evidence for the seasonal limitation of productivity either by silicate exhaustion in the case of diatoms or by iron $(\mathrm{Fe})$ limitation in the case of the wider phytoplankton community. However, unlike the surface waters of the subpolar northeastern Pacific (e.g. Martin and Fitzwater, 1988; Boyd et al., 1996) the subpolar North Atlantic was not widely recognised as an Fe limited system during initial studies of the area (Martin et al., 1993) due to early estimates of high aeolian dust inputs to the subpolar gyre ( $>1 \mathrm{~g}_{\text {dust }} \mathrm{m}^{-2} \mathrm{yr}^{-1}$ (Donaghay et al., 1991; Duce et al., 1991; Duce and Tindale, 1991), though these have subsequently been revised downwards $\left(<1 \mathrm{~g}_{\text {dust }} \mathrm{m}^{-2} \mathrm{yr}^{-1}\right.$ or $\sim 0.04 \mathrm{~g} \mathrm{Fe} \mathrm{m}^{-2} \mathrm{yr}^{-1}$; Jickells et al., 2005; Mahowald et al., 2009). Recently, Measures et al. (2008) and Nielsdottir et al. (2009) both reported low and potentially biologically limiting $\mathrm{Fe}$ concentrations within the Iceland Basin during the summer months (June-August). The mean surface iron concentration of $0.093 \mathrm{nmol} \mathrm{L}^{-1}$ reported by Nielsdottir et al. (2009) from observations made in 2007 was identical to the mean concentration reported independently by Measures et al. (2008) for observations made in 2003; though both estimates were almost two times higher than the low Fe concentrations reported as typical for the NE subarctic Pacific $\left(\sim 0.05 \mathrm{nmol} \mathrm{L}^{-1}\right.$ Harrison et al., 2004; Takeda, 2011). Coincident surface $\mathrm{NO}_{3}^{-}$concentrations reported by Nielsdottir et al. (2009) ranged from 2 to $5 \mu \mathrm{mol} \mathrm{L}{ }^{-1}$, similar to those reported by Sambrotto et al. (1993) for the Iceland Basin and to those reported by Sanders et al. (2005) for the Irminger Basin, leading Nielsdottir et al. (2009) to conclude that much of the North Atlantic subpolar gyre could be seasonally Fe limited. Confirmation that the summer phytoplankton community experiences $\mathrm{Fe}$ limitation has been presented by Nielsdottir et al. (2009) and Ryan-Keogh et al. (2013) with the latter study demonstrating the development of Fe stress during the spring bloom. Whilst these observations imply a similarity to other Fe limited regions such as the NE Pacific and Southern Ocean the subpolar North Atlantic is also quite distinct due to the presence of lower residual $\mathrm{NO}_{3}^{-}$concentrations during the summer, a pronounced phytoplankton spring bloom, prominent coccolithophore blooms and high summertime chlorophyll concentrations (Martin et al., 1993; Measures et al., 2008); features which are not present in other Fe limited regions. Thus questions over the extent, severity and variability of Fe limitation within the subpolar North Atlantic remain unanswered.

Fe limitation may be alleviated following the addition of Fe from a number of different sources and through a variety of mechanisms. This can include aeolian dust deposition
(Jickells et al., 2005; Mahowald et al., 2009), volcanic ash input (Watson 1997; Duggen et al., 2010), the supply of Fe from local continental shelves (Elrod et al., 2004; Planquette et al., 2007; Lam and Bishop 2008; Lam et al., 2012), physical supply from the deep ocean (Watson, 2001), hydrothermal inputs (Tagliabue et al., 2010; Saito et al., 2013) and more localised processes such as input via glacial meltwaters and iceberg carving (Statham et al., 2008; Bhatia et al., 2013; reviewed by Raiswell and Canfield, 2012). In most remote oceanic areas the aeolian supply is considered the dominant input of $\mathrm{Fe}$ (e.g. Croot et al., 2007) but the magnitude and even the significance of this supply term can vary regionally, seasonally and interannually (Jickells et al., 2005; Mahowald et al., 2009; Okin et al., 2011). For Fe to be supplied from the deep ocean appropriate mechanisms to access the deep ocean reservoir must be active (Watson 2001). One such mechanism that we investigate here is the role of diapycnal diffusion. The magnitude and spatial variability of diffusive macro- and micronutrient fluxes in the North Atlantic subpolar gyre has to date received limited study with previous efforts primarily located within the Iceland Basin (e.g. Jickells et al., 2008; Forryan et al., 2012).

\section{Methods}

\subsection{Cruise overview}

The majority of data presented in this study were collected between 4 July and 11 August 2010 as part of the RRS Discovery cruise D354 to the Iceland and Irminger Basins (Fig. 1). In advance of this cruise similar observations were obtained at nine stations in late April 2010 (RRS Discovery cruise D350). These observations were collected to provide an initial assessment of conditions at the start of the productive period and the data from the earlier April cruise are used to provide a seasonal context in the following.

Water samples were collected with both stainless steel and titanium framed Seabird 9/11+ CTD (conductivity, temperature, depth)-Niskin rosette packages using trace metal clean sampling techniques where appropriate. The depth of the euphotic zone ( $1 \%$ surface irradiance) was calculated following Morel et al. (2007) using MODIS-Aqua chlorophyll concentrations due to infrequent determination of the euphotic depth during the cruise. The euphotic depth varied from 29 to $49 \mathrm{~m}$ (mean $\pm 1 \mathrm{SD} 40 \pm 5 \mathrm{~m}$; SD: standard deviation), similar to our limited in situ measurements (33-44 m). Mixed layer depths (MLD) were taken at the depth of the local maximum in the Brunt-Väisälä buoyancy frequency profile (MLD range $17-49 \mathrm{~m}$, mean $\pm 1 \mathrm{SD} 28 \pm 8 \mathrm{~m}$ ). 


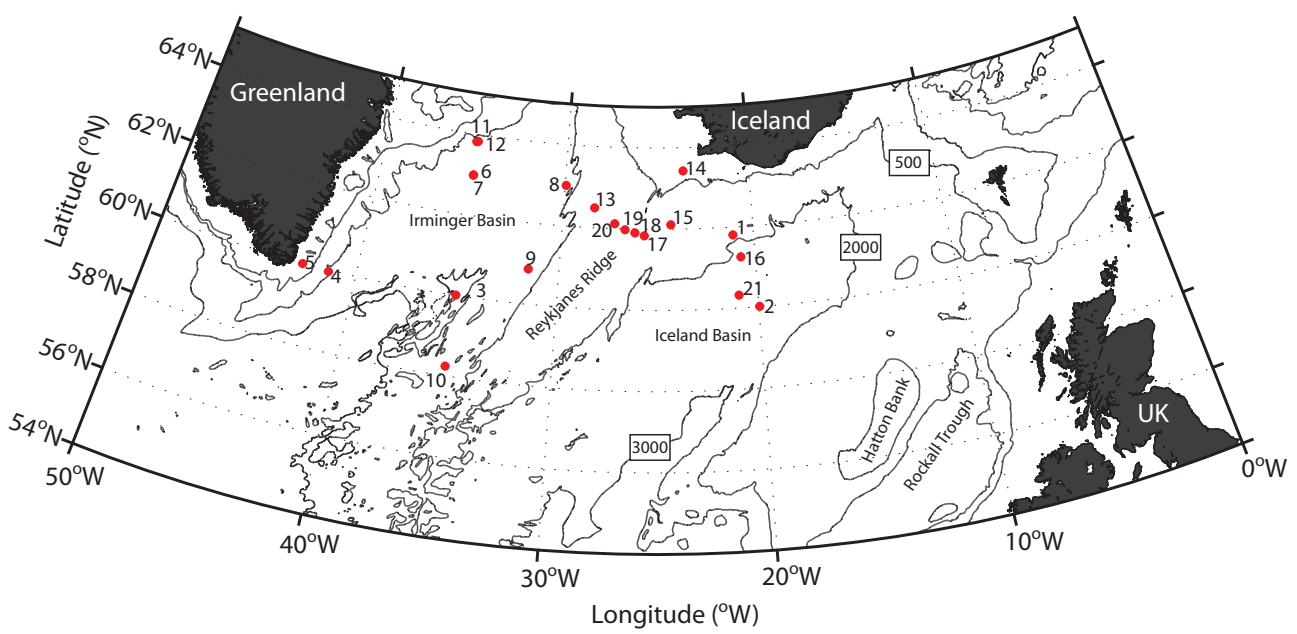

Fig. 1. Map showing the sub-basins of the North Atlantic subpolar gyre and the location of stations reported in this study. Also shown are adjacent land masses, major bathymetric features and key isobaths.

\subsection{Macronutrient and chlorophyll $a$ concentrations}

Water samples for the determination of total nitrate $\left(\mathrm{NO}_{3}^{-}\right.$ $+\mathrm{NO}_{2}^{-}$, hereafter $\left.\mathrm{NO}_{3}^{-}\right)$, phosphate $\left(\mathrm{PO}_{4}^{3-}\right)$ and orthosilicic acid $\left(\mathrm{Si}(\mathrm{OH})_{4}\right)$ concentrations were drawn directly from CTD Niskin bottles and from the ship fitted, non-toxic underway water system ( $5 \mathrm{~m}$ intake depth) into clear polystyrene vials and if not immediately analysed were stored $(<4 \mathrm{~h})$ in the dark at $4{ }^{\circ} \mathrm{C}$ whilst awaiting analysis. All concentrations were determined colorimetrically using a three channel Skalar Sanplus autoanalyser following the methods described by Kirkwood (1996). Detection limits of better than $0.1 \mu \mathrm{mol} \mathrm{L}-1$ for $\mathrm{NO}_{3}^{-}$and $\mathrm{Si}(\mathrm{OH})_{4}$ and $0.01 \mu \mathrm{mol} \mathrm{L}^{-1}$ for $\mathrm{PO}_{4}^{3-}$ were achieved throughout. Chlorophyll $a$ concentrations $\left(\mathrm{mg} \mathrm{m}^{-3}\right)$ were determined fluorometrically from $250 \mathrm{~mL}$ seawater samples filtered onto $25 \mathrm{~mm}$ Whatman $\mathrm{GF} / \mathrm{F}$ (glass fibre) filters (nominal pore size $\sim 0.7 \mu \mathrm{m}$ ) before pigment extraction in $8 \mathrm{~mL}$ of $90 \%$ acetone at $4{ }^{\circ} \mathrm{C}$ over a subsequent $18-20 \mathrm{~h}$ period. Pigment extracts were measured on a Turner Designs TD700 fluorometer following the method of Welschmeyer (1994) and calibrated against a pure chlorophyll $a$ standard (Sigma, UK).

\subsection{Trace metal (dFe and dAI) measurements}

The complete $\mathrm{dFe}$ (dissolved iron) and $\mathrm{dAl}$ (dissolved aluminium) data sets collected during this cruise programme along with full methodological details will be described elsewhere. Here we present a subset of the data coincident with profiles of turbulent diffusivity to estimate vertical diffusive fluxes into the mixed layer. Water samples for $\mathrm{dFe}(0.2 \mu \mathrm{m}$ filtered) and $\mathrm{dAl}(0.2 \mu \mathrm{m}$ filtered) analyses were collected from the titanium-framed CTD only which was fitted with $10 \mathrm{~L}$ sampling bottles with external springs modified for trace metal work. Upon recovery of the CTD package the trace metal clean sample bottles were transferred to a clean container laboratory for sample processing. Water samples were filtered using a Sartobran $300 \mathrm{MF}$ (membrane filter) $0.2 \mu \mathrm{m}$ filter cartridge and collected into clean $125 \mathrm{~mL}$ Nalgene LDPE (low-density polyethylene) bottles. Concentrations of $\mathrm{dFe}$ were determined back in the shore-based laboratory by isotope dilution inductively coupled plasma mass spectrometry (ID-ICPMS) as described by Milne et al. (2010), whilst concentrations of dAl were measured using the flow injection method of Resing and Measures (1994).

In the following we assume the measured dFe concentration represents the concentration of aqueous $\mathrm{Fe}$ in seawater. This however is a simplification as the Fe pool in the $<0.2 \mu \mathrm{m}$ size fraction is composed of aqueous, colloidal and nanoparticle species with different chemical properties (Raiswell and Canfield, 2012).

\subsection{Diffusivity measurements}

Turbulent kinetic energy dissipation $(\varepsilon)$ was measured at 21 stations across the subpolar gyre (Fig. 1) using an MSS90L free-fall microstructure shear profiler, produced by Sea and Sun Technology GmbH and ISW Wassermesstechnik. Assuming isotropic turbulence (Yamazaki and Osborn, 1990) the rate of turbulent kinetic energy dissipation was calculated from the variance of the measured vertical microstructure shear by integration of the vertical microstructure shear power spectrum $(\Phi(k))$, where $k$ is the wave number:

$\varepsilon=\frac{15}{2} v \int_{k_{l}}^{k_{c}} \Phi(k) \mathrm{d} k$,

(Moum et al., 1995; Rippeth et al., 2003; Stips, 2005) following the method of Forryan et al. (2012). Turbulent diffusivity (K) was calculated from turbulent kinetic energy dissipation 
using the relationship

$\varepsilon=\frac{K N^{2}}{\Gamma}$,

(Osborn, 1980) where $N$ is the buoyancy frequency and with a constant mixing efficiency of $\Gamma=0.2$ (Osborn, 1980; Moum et al., 1995; Rippeth et al., 2003). We excluded the upper $8 \mathrm{~m}$ of data to remove near surface influences before binning the diffusivity data into $4 \mathrm{~m}$ depth bins.

\subsection{Nutrient fluxes}

Nutrient fluxes into the surface mixed layer were calculated using vertical nutrient gradients and the diffusivity term via the equation $K \frac{\partial \mathrm{Nut}}{\partial z}$, where $K$ is the local vertical diffusivity, "Nut" the local nutrient concentration and $\frac{\partial N u t}{\partial z}$ the vertical nutrient gradient. Profiles of nutrient concentration were first linearly interpolated onto a regular $1 \mathrm{~m}$ grid to compensate for irregular sampling depths and nutrient gradients were then calculated between sequential depth bins. This approach made the extraction of nutrient gradients a slightly less subjective issue than trying to estimate mean gradients but also had the further benefit of allowing us to use a diffusivity value representative of a particular part of the water column. Values of $K$ and of $\frac{\partial \text { Nut }}{\partial z}$ were subsequently extracted at the relevant mixed layer depth and multiplied to produce estimates of the daily diffusive flux of $\mathrm{NO}_{3}^{-}, \mathrm{Si}(\mathrm{OH})_{4}, \mathrm{PO}_{4}^{3-}$, $\mathrm{dFe}$ and $\mathrm{dAl}$.

\subsection{Daily phytoplankton nutrient uptake and annual new production}

Direct measurements of daily phytoplankton nutrient uptake coincident with our estimates of diffusive nutrient flux are not available, but to provide an approximation we instead calculated the mean daily uptake based on the seasonal change in nutrient concentrations between spring and summer. To do this, stations from the cruise in July/August (D354) were paired with the nearest station conducted during April (D350) (Supplement, Fig. 1) and integrated to the depth of the mixed layer (mixed layer depths were comparable between cruises). Differences in the integrated concentrations between the paired stations were used to produce seasonal estimates of nutrient demand (i.e. $\Delta \mathrm{Nut}=\int \mathrm{Nut}_{0}-\int \mathrm{Nut}$ $\mathrm{t}_{1}$ ), which were subsequently divided by the time interval $(\Delta t)$ between each paired set of stations to produce approximate daily uptake rates (i.e. $\rho$ Nut $=\frac{\Delta \text { Nut }}{\Delta t}$ ). We recognise that this approach is relatively crude as it assumes a linear reduction in integrated concentrations between the two sampling periods, that nutrient drawdown most likely was highly non-linear, and that nutrient inputs are not considered. However, the resulting daily net nutrient uptake rate calculated in this way is both broadly representative of this particular system and provides an appropriate measure against which to compare turbulent diffusive fluxes. The daily estimates of
$\mathrm{NO}_{3}^{-}$demand calculated in this manner were also used in conjunction with widely used $\mathrm{C}: \mathrm{N}$ stoichiometric relationships (Redfield et al., 1963) and an estimate of the length of the annual productive period (from April to August - $154 \mathrm{~d}$; Sanders et al., 2005; Henson et al., 2006) to estimate total new production over the annual cycle.

In situ measurements of primary production and $\mathrm{NO}_{3}^{-}$uptake based on ${ }^{14} \mathrm{C}$ and ${ }^{15} \mathrm{~N}$ methodologies respectively (e.g. Poulton et al., 2010; Lucas et al., 2007) were measured at a single depth $(<10 \mathrm{~m})$ during the summer cruise and are presented here to provide some constraint upon the approximate daily rates described above.

\subsection{Atmospheric iron and aluminium supply}

Aerosol samples were collected onto Whatman 41 cellulose substrates using high volume samplers at a flow rate of $\sim 1 \mathrm{~m}^{3} \mathrm{~min}^{-1}$. All substrates were washed before use in $0.5 \mathrm{M}$ hydrochloric acid, followed by $0.1 \mathrm{M}$ hydrochloric acid as described in Rickli et al. (2010). A Sierra-type cascade impactor was employed to separate the samples into particles with aerodynamic diameters greater than or less than $1 \mu \mathrm{m}$. Collection times were generally $42-47 \mathrm{~h}$, giving total air volumes of $3100-3400 \mathrm{~m}^{3}$. Immediately after collection the substrates were sealed in individual ziplock plastic bags and stored frozen until later analysis. Soluble trace metals were extracted from portions of the aerosol samples using a $\sim 1 \mathrm{M}$ ammonium acetate leach solution buffered at $\mathrm{pH}$ 4.7 and analysed using inductively coupled plasma - optical emission spectroscopy (ICP-OES; Baker et al., 2007). Trace metal dry deposition fluxes $\left(F^{\text {dry }}, \mathrm{nmol} \mathrm{m}^{-2} \mathrm{~d}^{-1}\right)$ were calculated from aerosol concentrations $\left(C^{\text {aero }}, \mathrm{pmol} \mathrm{m}^{-3}\right)$ using Eq. 3:

$F^{\text {dry }}=C^{\text {aero }} v_{\mathrm{d}}$,

where $v_{\mathrm{d}}$ is the dry deposition velocity. Values of $v_{\mathrm{d}}$ were set to 1 and $0.1 \mathrm{~cm} \mathrm{~s}^{-1}$ for the coarse $(>1 \mu \mathrm{m})$ and fine $(<1 \mu \mathrm{m})$ aerosol modes respectively (Duce et al., 1991). Deposition velocities vary strongly as a function of particle size and wind speed (Ganzeveld et al., 1998) and are highly uncertain. Duce et al. (1991) estimate the uncertainty in $v_{\mathrm{d}}$ to be plus or minus a factor of 2-3.

Dry deposition fluxes represent only part of the atmospheric flux. Wet deposition fluxes $\left(F_{\mathrm{w}}\right)$ of soluble $\mathrm{Fe}$ and Al were estimated from $C^{\text {aero }}$ by applying a scavenging ratio $\left(S_{\mathrm{r}}\right)$ of 200 (Eq. 4; Duce et al., 1991):

$F_{\mathrm{w}}=P C^{\text {aero }} S_{\mathrm{r}} / \rho$,

where $P$ is the precipitation rate and $\rho$ is the density of air $\left(1200 \mathrm{~g} \mathrm{~m}^{-3}\right)$. An average precipitation rate of $\sim 2 \mathrm{~mm} \mathrm{~d}^{-1}$ for the months of July and August was obtained from the $2.5^{\circ} \times 2.5^{\circ}$ gridded monthly output of the CMAP model updated from Xie and Arkin (1997) (www.cdc.noaa.gov/cdc/ data.cmap.html). 

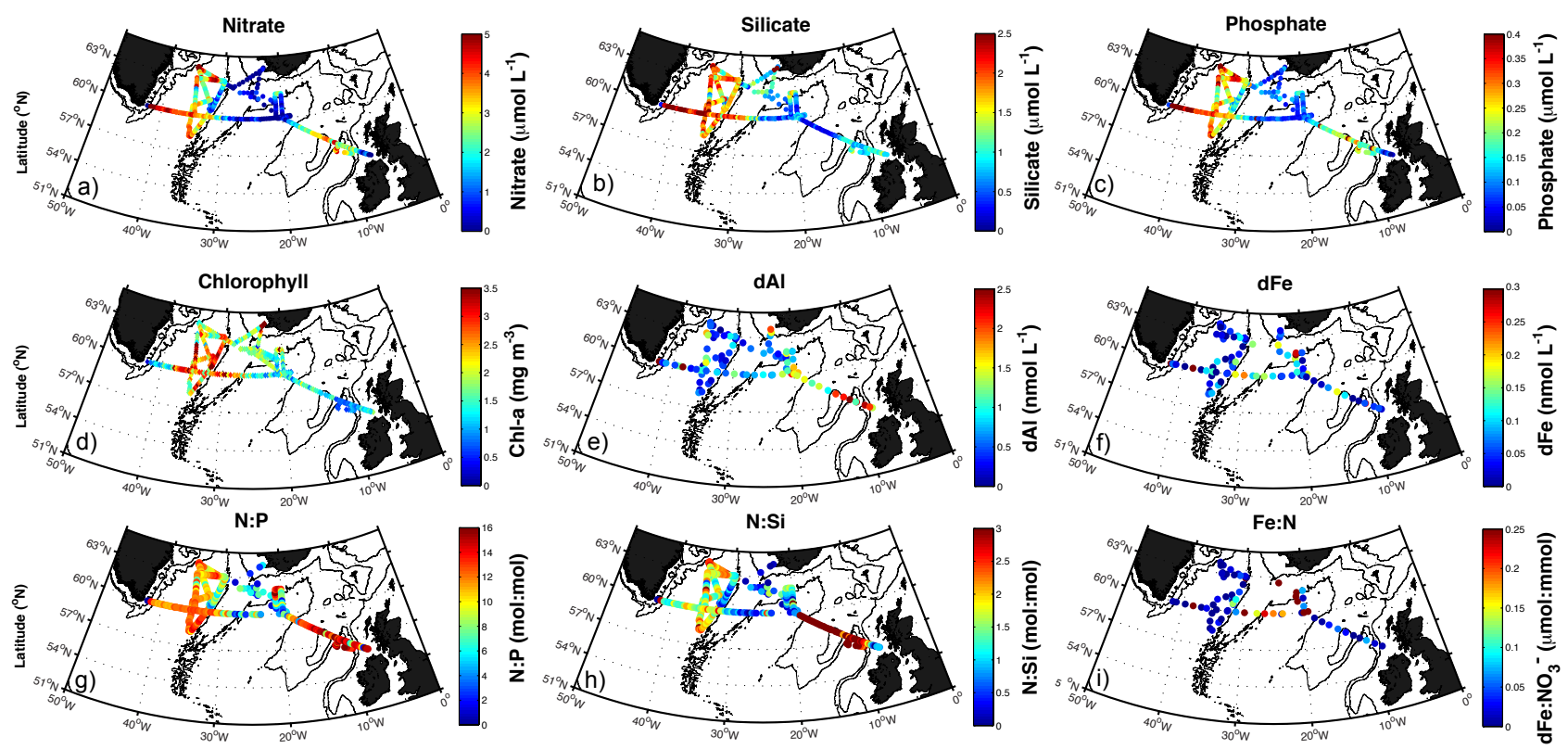

Fig. 2. Surface maps of summer (July-August) (a-c) macronutrient, (d) chlorophyll and (e, f) trace metal concentrations, and (g-i) major nutrient ratios in the surface ocean.

Table 1. Mean ( $\pm 1 \mathrm{SD}$ ) surface conditions, productivity rates (where sampled) and nutrient concentrations in various subsectors of the subpolar gyre as measured in July-August 2010. All state measurements are based on samples collected from the ship's non-toxic underway water supply (nominal depth $5 \mathrm{~m}$ ). The surface productivity rate measurements are based on water samples collected via CTD cast $(<10 \mathrm{~m}$ depth; SSS: sea surface salinity).

\begin{tabular}{|c|c|c|c|c|c|c|c|c|c|c|c|}
\hline Region/Feature & $\begin{array}{l}\text { MLD } \\
(\mathrm{m})\end{array}$ & $\begin{array}{l}\text { SST } \\
\left({ }^{\circ} \mathrm{C}\right)\end{array}$ & SSS & $\begin{array}{c}\text { Chl } a \\
\left(\mathrm{mg} \mathrm{m}^{-3}\right)\end{array}$ & $\begin{array}{c}\text { Production } \\
\left(\mathrm{mmol} \mathrm{C} \mathrm{m}^{-3} \mathrm{~d}^{-1}\right)\end{array}$ & $\begin{array}{c}\rho \mathrm{NO}_{3}^{-} \\
\left(\mathrm{mmol} \mathrm{N} \mathrm{m}^{-3} \mathrm{~d}^{-1}\right)\end{array}$ & $\left.\begin{array}{c}\mathrm{NO}_{3}^{-} \\
(\mu \mathrm{mol} \mathrm{L} \\
-1\end{array}\right)$ & $\begin{array}{c}\mathrm{PO}_{4}^{3-} \\
\left(\mu \mathrm{mol} \mathrm{L}^{-1}\right)\end{array}$ & $\begin{array}{c}\mathrm{Si}(\mathrm{OH})_{4} \\
\left(\mu \mathrm{mol} \mathrm{L}^{-1}\right)\end{array}$ & $\begin{array}{c}\mathrm{dFe} \\
\left(\mathrm{nmol} \mathrm{L}^{-1}\right)\end{array}$ & $\begin{array}{c}\mathrm{dAl} \\
\left(\mathrm{nmol} \mathrm{L}^{-1}\right)\end{array}$ \\
\hline Irminger Basin & & & $34.91 \pm 0.11$ & $2.36 \pm 0.75$ & & $0.09 \pm 0.04$ & $3.13 \pm 1.34$ & $0.28 \pm 0.09$ & & & $0.65 \pm 0.72$ \\
\hline Iceland Basin & $28 \pm 9$ & $13.21 \pm 0$ & $94 \pm 0.14$ & & $2.69 \pm 0.6$ & .01 & & & & & \\
\hline Greenland Shelf & $26 \pm 12$ & $7.36 \pm 3.44$ & $33.53 \pm 1.98$ & $1.02 \pm 0.52$ & $2.03 \pm 0$ & $0.05 \pm 0$ & $3.9 \pm 3.1$ & $0.33 \pm 0.22$ & $2.22 \pm 1.76$ & $0.17 \pm 0.24$ & $2.05 \pm 2.36$ \\
\hline Hatton Bank & $42 \pm 4$ & $12.68 \pm 0.17$ & $35.27 \pm 0.09$ & $1.3 \pm 0.36$ & - & - & $2.91 \pm 0.86$ & $0.23 \pm 0.08$ & $0.51 \pm 0.34$ & $0.06 \pm 0.07$ & $1.72 \pm 0.68$ \\
\hline Rockall Trough & - & $13.38 \pm 0.32$ & $35.4 \pm 0.01$ & $0.76 \pm 0.17$ & - & - & $2.93 \pm 0.68$ & $0.21 \pm 0.07$ & $0.86 \pm 0.21$ & $0.13 \pm 0.12$ & $1.93 \pm 0.72$ \\
\hline
\end{tabular}

\section{Results}

\subsection{Macronutrient and chlorophyll concentrations}

Surface macronutrient concentrations ranged from $<0.1$ to $6.47 \mu \mathrm{mol} \mathrm{L}^{-1}$ for $\mathrm{NO}_{3}^{-}$, from 0.12 to $4.31 \mu \mathrm{mol} \mathrm{L}^{-1}$ for $\mathrm{Si}(\mathrm{OH})_{4}$ and from $<0.01$ to $0.54 \mu \mathrm{mol} \mathrm{L}^{-1}$ for $\mathrm{PO}_{4}^{3-}$. There was considerable spatial variability, and a strong zonal gradient between the Iceland and Irminger basins was evident with higher surface nutrient concentrations in the Irminger Basin than in the Iceland Basin (Fig. 2, Table 1). The low nutrient concentrations of the Iceland Basin extended from the Reykjanes Ridge $\left(\sim 30^{\circ} \mathrm{W}\right)$ to Hatton Bank $\left(\sim 15^{\circ} \mathrm{W}\right)$ and included waters of the Icelandic Shelf $\left(\sim 63^{\circ} \mathrm{N}\right)$, which were the most $\mathrm{NO}_{3}^{-}$impoverished waters of the entire region with concentrations below the limit of detection $\left(<0.1 \mu \mathrm{mol} \mathrm{L}^{-1}\right)$. The highest surface nutrient concentrations were found in the western Irminger Basin where $\mathrm{NO}_{3}^{-}, \mathrm{Si}(\mathrm{OH})_{4}$ and $\mathrm{PO}_{4}^{3-}$ concentrations were typically $>4 \mu \mathrm{mol} \mathrm{L}^{-1},>2 \mu \mathrm{mol} \mathrm{L}^{-1}$, and $>0.3 \mu \mathrm{mol} \mathrm{L}^{-1}$ re- spectively (Fig. 2). Exceptions to this general pattern were two stations located on the Greenland Shelf $\left(\sim 42^{\circ} \mathrm{W}\right)$ where surface nutrient concentrations were markedly lower at $<$ $0.02 \mu \mathrm{mol} \mathrm{L}^{-1}, 0.27 \mu \mathrm{mol} \mathrm{L}^{-1}$ and $0.03 \mu \mathrm{mol} \mathrm{L}^{-1}$ for $\mathrm{NO}_{3}^{-}$, $\mathrm{Si}(\mathrm{OH})_{4}$ and $\mathrm{PO}_{4}^{3-}$ respectively (Fig. 2). These lower nutrient concentrations reflect both the occurrence of earlier and stronger phytoplankton blooms on the shelf compared to the central Irminger Basin, which will have reduced nutrient concentrations (Waniek et al., 2005) and the influence of the southward flowing East Greenland Current (Bacon et al., 2002; Wilkinson and Bacon, 2005).

Surface chlorophyll $a$ concentrations indicated widespread patchiness and distinct regional variability. The highest chlorophyll concentrations $\left(>6 \mathrm{mg} \mathrm{m}^{-3}\right)$ were found on the Icelandic Shelf but elsewhere chlorophyll concentrations were lower; typically $<4 \mathrm{mg} \mathrm{m}^{-3}$ in the Irminger Basin, $<1.5 \mathrm{mg} \mathrm{m}^{-3}$ in the Iceland Basin and $<0.8 \mathrm{mg} \mathrm{m}^{-3}$ in Rockall Trough (Fig. 2, Table 1). Despite significant variability within individual sub-basins chlorophyll concentrations increased zonally from east to west, 
peaking at $\sim 4.6 \mathrm{mg} \mathrm{m}^{-3}$ along the western flank of the Reykjanes Ridge and westward into the Irminger Basin. West of $40^{\circ} \mathrm{W}$, concentrations decreased reaching a local minimum of $<0.3 \mathrm{mg} \mathrm{m}^{-3}$ on the Greenland Shelf.

\subsection{Trace metal concentrations}

Surface concentrations of dAl varied from below the limit of detection (three times the standard deviation of the blank or $0.36 \mathrm{nmol} \mathrm{L}^{-1}$ ) to $5.7 \mathrm{nmol} \mathrm{L}^{-1}$ across the region (Fig. 2). $\mathrm{dAl}$ concentrations tended to decrease zonally towards the west with the lowest concentrations measured within the Irminger Basin (Table 1). The highest concentrations were found on the Greenland Shelf $\left(>2 \mathrm{nmol} \mathrm{L}^{-1}\right)$. Surface concentrations of $\mathrm{dFe}$ were generally $<0.2 \mathrm{nmol} \mathrm{L}^{-1} \mathrm{ev}$ erywhere but with a few isolated exceptions where $\mathrm{dFe}$ concentrations exceeded $0.4 \mathrm{nmol} \mathrm{L}^{-1}$ (Fig. 2). The mean ( $\pm 1 \mathrm{SD}$ ) surface $\mathrm{dFe}$ concentration for the entire data set was $0.092 \pm 0.184 \mathrm{nmol} \mathrm{L}^{-1}$ but subtle geographic patterns underlie this broader generalisation (Table 1). The highest mean $\mathrm{dFe}$ concentrations of $0.13 \pm 0.12$ and $0.17 \pm 0.24 \mathrm{nmol} \mathrm{L}^{-1}$ were found in the surface waters of the Rockall Trough and Greenland Shelf respectively. Elsewhere and in particular within the surface waters of the Iceland and Irminger Basins the mean $\mathrm{dFe}$ concentration was $<0.08 \mathrm{nmol} \mathrm{L}^{-1}$ (Table 1), slightly lower than reported in recent studies (Measures et al., 2008; Nielsdottir et al., 2009).

$\mathrm{Fe}$ is often described as having a nutrient-like vertical distribution due to the near surface reduction in concentration due to biological demand and the increase in concentration with depth. Whilst this was generally true of the data collected during this study, a number of profiles also exhibited subsurface minima or maxima at or below the base of the mixed layer. Due to the repeated appearance of these features and their significance for the calculation of daily diffusive fluxes we briefly describe two examples. In cases where a subsurface maximum was observed such that an inversion in the $\mathrm{dFe}$ profile was the result (Fig. 3), we consider it likely that this resulted from the remineralisation of sinking organic matter leading to a localised accumulation of $\mathrm{dFe}$, as has been noted elsewhere (Strzepek et al., 2005). In contrast, for those profiles where a subsurface minimum was observed (Fig. 3) we consider this representative of either a recent influx of $\mathrm{Fe}$ to the surface waters above, thereby increasing near surface (mixed layer) concentrations or due to biological demand reducing $\mathrm{dFe}$ concentrations within a particular depth stratum of the water column. Similar features were also apparent in the vertical profiles of dAl but not necessarily at the same stations and consequently are likely to have rather different causes due to the general lack of biological demand for dAl (but see Koning et al., 2007). As a result of these subsurface maxima or minima the calculation of vertical iron gradients and the subsequent calculation of the daily diffusive flux could be skewed by the sign of the gradient; one of several problems that complicates the interpretation of diffu- sive iron fluxes (Croot et al., 2007). As we believe there are reasonable grounds for interpreting these subsurface maxima and minima as real features resulting from either the addition or removal of $\mathrm{dFe}$ or $\mathrm{dAl}$ we keep the following analysis as simple as possible by including negative gradients if such are considered reflective of the actual profile.

\subsection{Nutrient ratios}

Surface maps for the nutrient ratios $\mathrm{N}: \mathrm{P}, \mathrm{N}: \mathrm{Si}$ and dFe : $\mathrm{NO}_{3}^{-}$are presented in Fig. $2 . \mathrm{N}: \mathrm{P}$ ratios were broadly in agreement with the Redfield stoichiometric assumption (i.e. $\sim 16: 1$ ) but were variable and ranged from 0.29 to 19.65: $1 \mathrm{~mol}: \mathrm{mol}$. The widespread presence of $\mathrm{N}: \mathrm{P}$ ratios $<16: 1$ in the Iceland Basin was readily identifiable and implied a residual nutrient pool depleted in $\mathrm{NO}_{3}^{-}$relative to $\mathrm{PO}_{4}^{3-}$. Compared to other studies in this area (e.g. Sambrotto et al., 1993) the occurrence of $\mathrm{NO}_{3}^{-}$impoverished surface waters appears unusual for this basin and it is not clear from this single data set if low $\mathrm{N}$ : P ratios are typical for these waters in late summer (but see Stefansson and Olafsson, 1991). Within the data we identified three geographical sectors. In the eastern sector of the subpolar gyre, defined as the region between the UK and the western flank of Hatton Bank (i.e. Rockall Trough), the N:P ratio was approximately $15: 1$ mol:mol, close to balanced Redfield stoichiometry. In the central sector, represented by the Iceland Basin, the $\mathrm{N}: \mathrm{P}$ ratio decreased markedly from the Redfield ratio but $\mathrm{N}: \mathrm{P}$ ratios were also highly variable in this area. In general the $\mathrm{N}: \mathrm{P}$ ratio was $<8: 1 \mathrm{~mol}: \mathrm{mol}$, though isolated occurrences of $\mathrm{N}: \mathrm{P}$ ratios of $12-15: 1 \mathrm{~mol}: \mathrm{mol}$ were still evident. In the western sector, west of the Reykjanes Ridge (i.e. Irminger Basin), N : P ratios were between 11-14: $1 \mathrm{~mol}$ : mol, and though higher than measurements from the central Iceland Basin they remained lower than the $\mathrm{N}$ : P ratios from Rockall Trough. On the Greenland Shelf surface N : P values were quite distinct being unusually low at $0.3: 1 \mathrm{~mol}: \mathrm{mol}$. This tripartite distribution pattern of $\mathrm{N}: \mathrm{P}$ ratios argues strongly for localised and perhaps even distinct biogeochemical processes operating within the three sectors (provinces) of the subpolar gyre. In particular, the excess $P$ signature seen in the western subpolar gyre is potentially indicative of a greater influence from the P-rich Arctic outflow (Torres-Valdes et al., 2013) compared to the Iceland Basin.

The N:Si ratio was equally variable (Fig. 2). Heading west from the UK towards Hatton Bank surface $\mathrm{N}$ : Si ratios steadily increased from initial values of around $1: 1$ mol: mol, briefly plateaued around 2-4:1 mol: mol in the Rockall Trough, before peaking at 13.4:1 mol:mol over Hatton Bank, where surface $\mathrm{Si}(\mathrm{OH})_{4}$ concentrations were very low relative to $\mathrm{NO}_{3}^{-}$concentrations. In the Iceland Basin $\mathrm{N}$ : Si ratios were typically $<1: 1 \mathrm{~mol}: \mathrm{mol}$ and west of the Reykjanes Ridge N : Si ratios increased to between 1 and $3: 1 \mathrm{~mol}:$ mol being closer to $1: 1 \mathrm{~mol}: \mathrm{mol}$ in the western part of the Irminger Basin. 

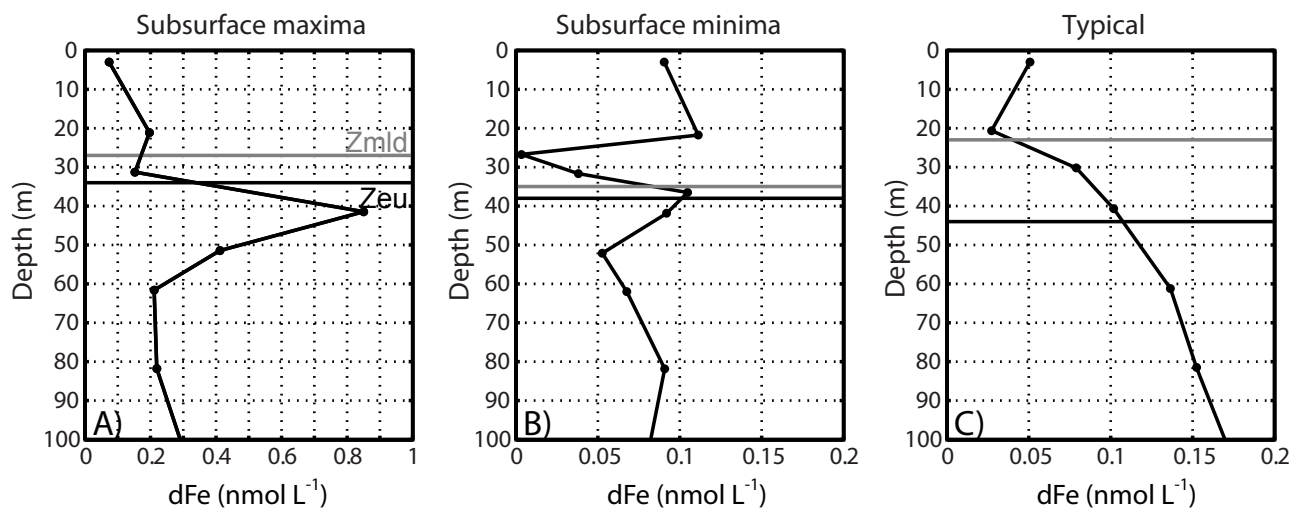

Fig. 3. Example vertical profiles of total dFe concentrations, which exhibit pronounced subsurface maxima or minima in the vertical compared to a more typical nutrient like vertical distribution. On each panel the mixed layer depth (Zmld) and euphotic depth (Zeu) are indicated by gray and black horizontal lines respectively.
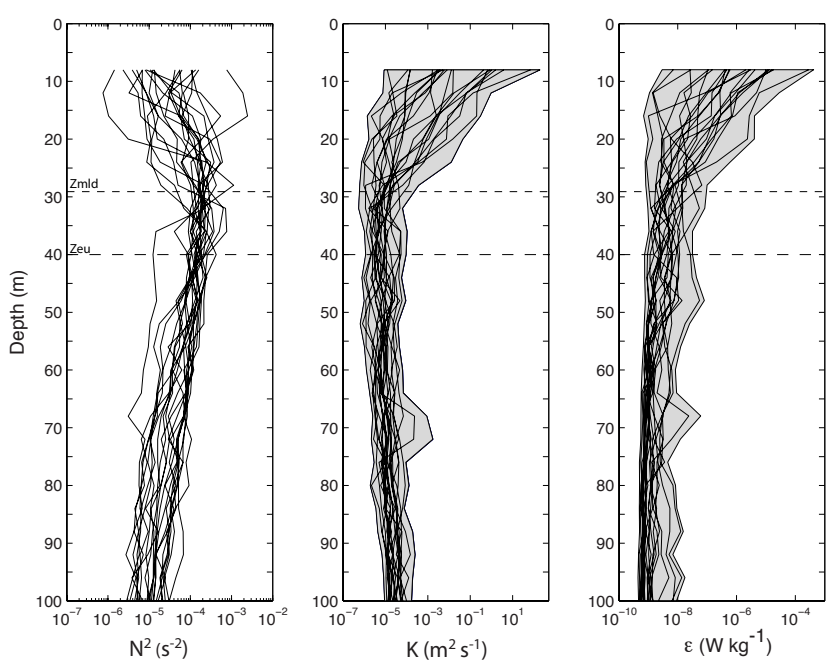

Fig. 4. Vertical profiles to $100 \mathrm{~m}$ depth of (a) the Brunt-Väisälä buoyancy frequency, (b) turbulent diffusivity (black lines) with $95 \%$ confidence interval envelope (grey shading) and (c) turbulent kinetic energy dissipation ( $\varepsilon$; black lines) with $95 \%$ confidence interval envelope (grey shading). Horizontal dashed lines represent the cruise mean Zmld and the cruise mean Zeu.

The ratio of $\mathrm{dFe}: \mathrm{NO}_{3}^{-}$in surface waters varied from 0.01 to $1.61 \mu \mathrm{mol}$ : mol (Fig. 2). Values were typically $0.05-$ $0.1 \mu \mathrm{mol}$ : mol between the UK and Hatton Bank, elevated to above 0.2 and as high as $1.6 \mu \mathrm{mol}: \mathrm{mmol}$ in the Iceland Basin, and below $0.05 \mu \mathrm{mol}: \mathrm{mmol}$ in the Irminger Basin. This particular pattern suggested that the waters of the Iceland Basin, despite having the lowest $\mathrm{NO}_{3}^{-}$concentrations of the region (Fig. 2) were proportionately enriched in $\mathrm{dFe}$ relative to $\mathrm{NO}_{3}^{-}$compared to the waters of the Irminger Basin. This finding could explain why surface $\mathrm{NO}_{3}^{-}$concentrations were lower than expected in the Iceland Basin.

The spatial variability displayed by the nutrient fields and the nutrient ratios indicated that generalities over what con- stituted typical summer conditions was dependent upon the particular sub-basin being examined. In particular, observations made in the Iceland Basin may not be reflective of conditions in the Irminger Basin due to significantly different nutrient conditions and apparent differences in the possible limiting nutrient. Consequently the overall biogeochemical nature, and character, of the sub-basins of the subpolar gyre need to be more fully recognised within general assessments of the biogeochemistry of the North Atlantic subpolar gyre.

\subsection{Diffusivity}

Profiles of vertical diffusivity are shown for all 21 stations in Fig. 4. Diffusivities within the surface mixed layer were quite variable and elevated in response to near surface turbulent events (wind action, waves) reaching $1-100 \mathrm{~cm}^{2} \mathrm{~s}^{-1}$ $\left(1 \times 10^{-4}-1 \times 10^{-2} \mathrm{~m}^{2} \mathrm{~s}^{-1}\right)$. The background diffusivity, which we calculate at $100 \mathrm{~m}$ depth, was $0.34 \pm 0.22 \mathrm{~cm}^{2} \mathrm{~s}^{-1}$ (equivalent to $3.38 \pm 2.29 \times 10^{-5} \mathrm{~m}^{2} \mathrm{~s}^{-1}$ ). A local minimum in diffusivity was typically identified close to the base of the mixed layer indicating a general tendency for diffusivities to decrease slightly from the background value in this region. Individual diffusivity measurements at the base of the mixed layer ranged from 0.01 to $0.5 \mathrm{~cm}^{2} \mathrm{~s}^{-1}$ with a cruise median value of $0.07 \mathrm{~cm}^{2} \mathrm{~s}^{-1}$. These estimates are broadly comparable to previous assessments made using a variety of techniques both within the subpolar region and within the wider North Atlantic (Table 2).

\subsection{Diffusive fluxes}

Diffusive nutrient fluxes into the mixed layer and the magnitude of these fluxes relative to mixed layer nutrient inventories are presented in Tables 3 and 4. A striking feature to the data was both the variability between stations and the presence of negative fluxes of $\mathrm{dFe}$ and $\mathrm{dAl}$, which implied downward rather than upward fluxes (due to the presence of inversions within the vertical $\mathrm{dFe}$ and $\mathrm{dAl}$ profiles; Fig. 3). 
Table 2. Literature estimates of vertical turbulent diffusivity rates obtained via multiple techniques from the present study and other studies within the wider North Atlantic Ocean.

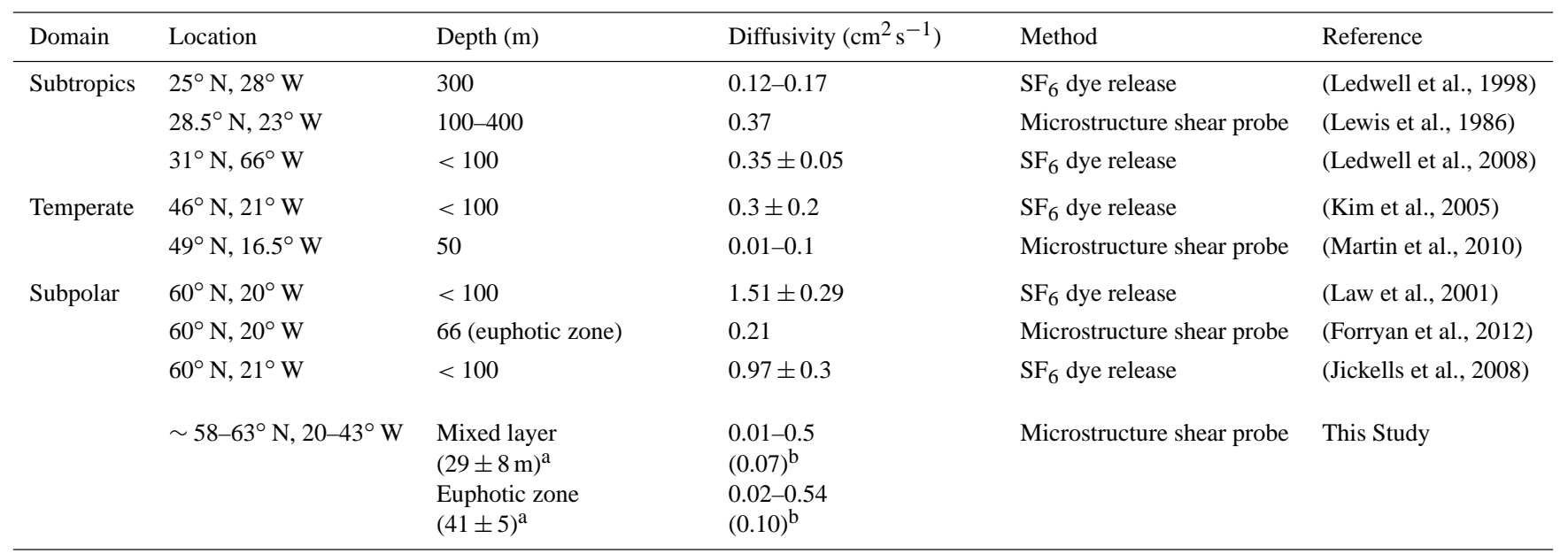

a Values in parentheses represent the mean $\pm \mathrm{SD}$ value for the full cruise data set.

${ }^{b}$ Values in parentheses represent the median value for the full cruise data set at the stated depth horizon.

Table 3. Macronutrient and trace metal diffusive fluxes into the surface mixed layer of the North Atlantic subpolar gyre in July-August 2010. Due to the significant variability between stations and the presence of both positive (upward) and negative (downward) dFe and dAl fluxes we calculate median fluxes in both directions. Note that a single station can have both an upward dFe flux and a downward dAl flux.

\begin{tabular}{|c|c|c|c|c|c|c|c|c|c|}
\hline $\begin{array}{l}\text { Turbulence } \\
\text { station }\end{array}$ & $\begin{array}{l}\text { Latitude } \\
\left({ }^{\circ} \mathrm{N}\right)\end{array}$ & $\begin{array}{l}\text { Longitude } \\
\left({ }^{\circ} \mathrm{W}\right)\end{array}$ & $\begin{array}{l}\text { Mixed layer } \\
\text { depth (m) }\end{array}$ & $\begin{array}{l}\text { Diffusivity } \\
\left(\mathrm{cm}^{2} \mathrm{~s}^{-1}\right)\end{array}$ & $\begin{array}{l}\mathrm{NO}_{3}^{-} \text {flux } \\
\left(\mu \mathrm{molm} \mathrm{m}^{-2} \mathrm{~d}^{-1}\right)\end{array}$ & $\begin{array}{l}\mathrm{Si}(\mathrm{OH})_{4} \text { flux } \\
\left(\mu \mathrm{molm}^{-2} \mathrm{~d}^{-1}\right)\end{array}$ & $\begin{array}{l}\mathrm{PO}_{4}^{3-} \text { flux } \\
\left(\mu \mathrm{molm}^{-2} \mathrm{~d}^{-1}\right)\end{array}$ & $\begin{array}{l}\text { dFe flux } \\
\left(\text { nmolm }^{-2} \mathrm{~d}^{-1}\right)\end{array}$ & $\begin{array}{l}\text { dAl flux } \\
\left(\mathrm{nmolm}^{-2} \mathrm{~d}^{-1}\right)\end{array}$ \\
\hline 1 & 61.81 & 21.07 & 23 & 0.03 & 233.1 & 79.7 & 13.8 & 3.33 & 33.95 \\
\hline 2 & 60.01 & 19.96 & 35 & 0.04 & 163.2 & 61.7 & 8.3 & 5.74 & 33.70 \\
\hline 3 & 60.01 & 34.98 & 49 & 0.50 & 651.2 & 161.7 & 45.3 & -0.43 & -6.47 \\
\hline 4 & 59.96 & 41.36 & 37 & 0.09 & 127.1 & 42.4 & 6.7 & 1.25 & 37.15 \\
\hline 5 & 59.99 & 42.69 & 17 & 0.48 & 165.1 & 60.5 & 34.9 & $-183.03^{\mathrm{a}}$ & $-1895.42^{\mathrm{a}}$ \\
\hline 6 & 62.99 & 35.01 & 17 & 0.20 & 391.0 & 129.6 & 20.1 & 3.14 & -25.32 \\
\hline 7 & 63.00 & 35.00 & 23 & 0.04 & 167.6 & 54.7 & 9.0 & 5.62 & 16.29 \\
\hline 8 & 63.00 & 29.95 & 25 & 0.07 & 34.2 & 4.4 & 2.5 & -0.42 & 7.93 \\
\hline 9 & 60.87 & 31.55 & 35 & 0.03 & 59.9 & 23.9 & 3.6 & 2.38 & 3.58 \\
\hline 10 & 58.24 & 34.98 & 39 & 0.03 & 127.3 & 39.5 & 6.1 & 21.11 & -7.79 \\
\hline 11 & 63.82 & 35.10 & 25 & 0.12 & 160.3 & 46.5 & 8.5 & -10.38 & -3.34 \\
\hline 12 & 63.83 & 35.02 & 31 & 0.12 & 43.6 & 25.4 & 4.1 & -0.13 & 8.12 \\
\hline 13 & 62.49 & 28.35 & 23 & 0.04 & 126.9 & 25.1 & 7.1 & 0.14 & -8.93 \\
\hline 14 & 63.43 & 23.60 & 25 & 0.08 & 254.8 & 18.3 & 18.3 & 0.66 & 7.86 \\
\hline 15 & 62.11 & 24.30 & 35 & 0.04 & 264.1 & 41.9 & 14.5 & -0.93 & 3.43 \\
\hline 16 & 61.26 & 20.73 & 27 & 0.01 & 22.1 & 4.4 & 1.1 & 0.17 & -0.84 \\
\hline 17 & 61.84 & 25.69 & 23 & 0.15 & 134.0 & 14.4 & 4.6 & -4.10 & 15.04 \\
\hline 18 & 61.91 & 26.18 & 29 & 0.11 & 147.4 & 19.0 & 9.5 & -0.69 & -9.50 \\
\hline 19 & 61.98 & 26.70 & 23 & 0.01 & 47.2 & 9.8 & 2.6 & - & 1.68 \\
\hline 20 & 62.12 & 27.25 & 25 & 0.25 & 297.3 & 92.1 & 20.2 & - & -49.55 \\
\hline 21 & 60.32 & 20.94 & 31 & 0.02 & 19.0 & 9.1 & 6.7 & -2.73 & 2.15 \\
\hline Median & - & - & - & 0.07 & 147.4 & 39.5 & 8.3 & 0.14 & 2.2 \\
\hline Median up & - & - & - & - & - & - & - & 2.76 & 8.0 \\
\hline Median down & - & - & - & - & - & - & - & -0.93 & -8.9 \\
\hline
\end{tabular}

a This station was located on the Greenland Shelf.

Nutrient gradients at the base of the mixed layer ranged from 41 to $904 \mu \mathrm{mol} \mathrm{m}{ }^{-4}$ for $\mathrm{NO}_{3}^{-}$, from 7 to $309 \mu \mathrm{mol} \mathrm{m}{ }^{-4}$ for $\mathrm{Si}(\mathrm{OH})_{4}$ and from 4 to $54 \mu \mathrm{mol} \mathrm{m}{ }^{-4}$ for $\mathrm{PO}_{4}^{3-}$. These gradients, in conjunction with the respective turbulent diffusivities, resulted in fluxes of $19-651 \mu \mathrm{mol} \mathrm{m}{ }^{-2} \mathrm{~d}^{-1}$ for $\mathrm{NO}_{3}^{-}$, 4-162 $\mu \mathrm{mol} \mathrm{m}^{-2} \mathrm{~d}^{-1}$ for $\mathrm{Si}(\mathrm{OH})_{4}$ and $1-45 \mu \mathrm{mol} \mathrm{m}^{-2} \mathrm{~d}^{-1}$ for $\mathrm{PO}_{4}^{3-}$ (Table 3). These fluxes represented between 0.02 and $3.9 \%$ (median $0.14 \%$ ) for $\mathrm{NO}_{3}^{-}, 0.01$ and $0.88 \%$ (median 0.08 ) for $\mathrm{Si}(\mathrm{OH})_{4}$, and 0.03 and $1.73 \%$ (median $0.09 \%$ ) for $\mathrm{PO}_{4}^{3-}$ of mixed layer nutrient inventories (Ta- ble 4). Collectively these results indicated that the turbulent fluxes were a rather minor source of nutrients to the surface ocean. The flux of $\mathrm{dFe}$ and $\mathrm{dAl}$ was complicated by the presence of both upward (positive) and downward (negative) flux terms (Table 3). For the data set as a whole, there was a negligible input of $\mathrm{dFe}$ with a median rate of supply of $0.14 \mathrm{nmolm}^{-2} \mathrm{~d}^{-1}$, equivalent to just $0.001 \%$ of the mixed layer dFe content (Table 4). Positive gradients in $\mathrm{dFe}$ at the base of the mixed layer ranged from 0.4 to $78 \mathrm{nmol} \mathrm{m}^{-4}$ and the resulting upward flux of $\mathrm{dFe}$ 


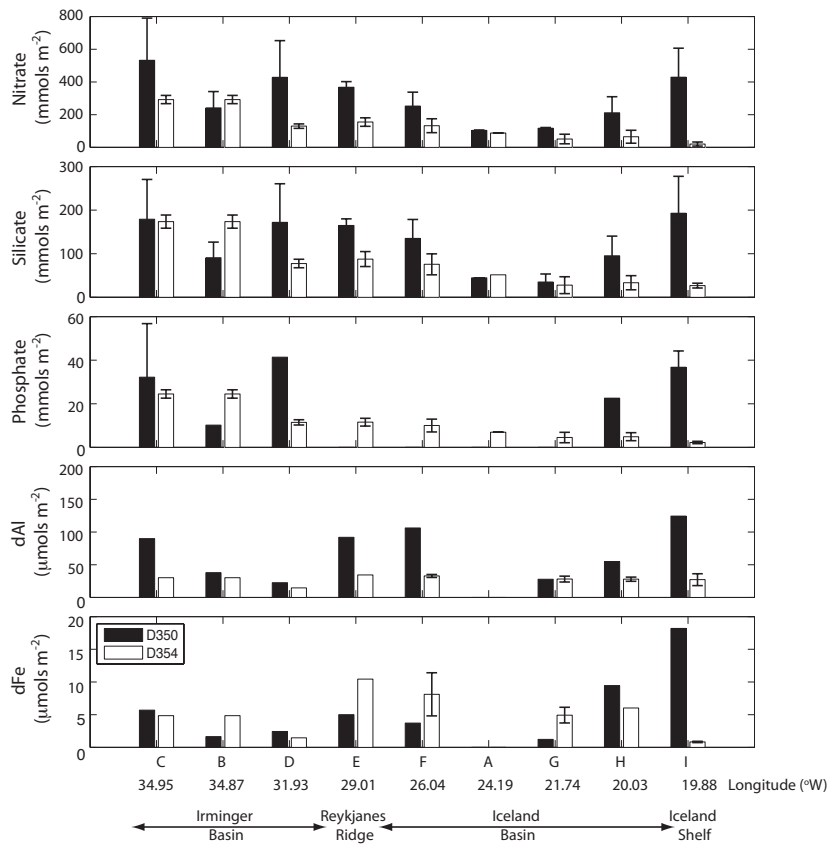

Fig. 5. Mixed layer integrated nutrient inventories during April and August 2010. Estimates of seasonal nutrient drawdown occurring within the mixed layer of the water column were calculated by the difference between late April and early August 2010. Drawdown estimates are focussed on the nine stations sampled in late April (Supplement, Fig. 1). When multiple profiles were obtained within a small geographical area around the main nine stations, the profiles were averaged and the standard deviation calculated (error bars). Phosphate data for comparisons A, E, F, and G not available for the spring cruise (D350). Note that all sampling stations have been reordered on longitude, as shown at the bottom of the plot to better represent the zonal distribution of stations. A similar assessment to $100 \mathrm{~m}$ depth is presented in Supplement Fig. 2.

ranged from 0.14 to $21.1 \mathrm{nmol} \mathrm{m}^{-2} \mathrm{~d}^{-1}$, with a median value of $2.76 \mathrm{nmolm}^{-2} \mathrm{~d}^{-1}$. These upward fluxes represented between 0.001 and $1.05 \%$ of mixed layer $\mathrm{dFe}$ inventories at individual stations but the median value was equivalent to just $0.1 \%$ of the mixed layer $\mathrm{dFe}$ content. The downward fluxes of $\mathrm{dFe}$ varied from -0.13 to $-183 \mathrm{nmol} \mathrm{m}^{-2} \mathrm{~d}^{-1}$ with a median downward flux of $-0.93 \mathrm{nmolm}^{-2} \mathrm{~d}^{-1}$. This loss term was equivalent to $0.05 \%$ of the mixed layer inventories. As for the macronutrients, the vertical daily diffusive flux of $\mathrm{dFe}$ therefore represented a negligible supply term to the mixed layer. The significant variability between stations and the limited size of the data set makes a regional diffusive $\mathrm{Fe}$ flux calculation problematic. Nevertheless using all available stations irrespective of flux direction we estimate median fluxes to the Iceland Basin of $1.75 \mathrm{nmol} \mathrm{dFe} \mathrm{m}^{-2} \mathrm{~d}^{-1}$, and to the Irminger Basin of $1.25 \mathrm{nmoldFe} \mathrm{m}^{-2} \mathrm{~d}^{-1}$. These in turn equate to annual fluxes of $0.64 \mu \mathrm{mol} \mathrm{dFe} \mathrm{m}^{-2} \mathrm{yr}^{-1}$ and $0.46 \mu \mathrm{mol} \mathrm{dFe} \mathrm{m}^{-2} \mathrm{yr}^{-1}$ to the Iceland and Irminger basins respectively. Thus to first order the Irminger Basin appeared to receive less Fe via diffusion than the Iceland Basin.
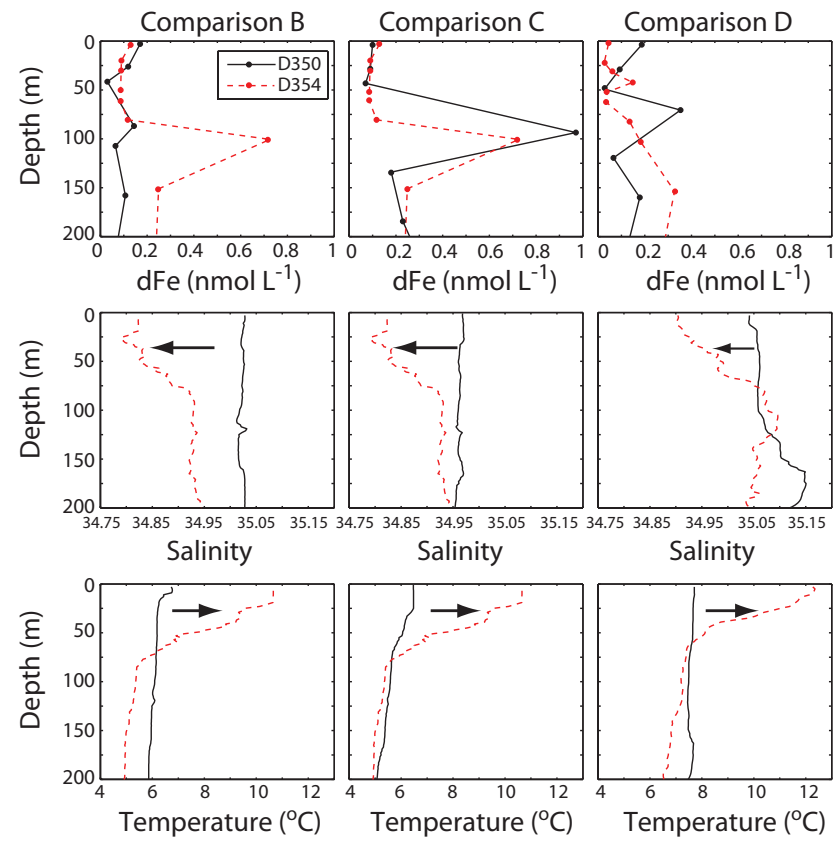

Fig. 6. Vertical profiles of total $\mathrm{dFe}$, salinity and temperature at the three sets of grouped stations sampled within the Irminger Basin (these groups are labelled B, C and D in Supplement Fig. 1). Between the two sampling periods increases in near-surface temperature and decreases in near-surface salinity indicate the arrival of warmer but fresher water into the Irminger Basin. There is some suggestion of coincident changes to the profiles of dFe with a subsequent impact on the size of the integrated $\mathrm{dFe}$ pool.

A similar complication was evident in the estimates of diffusive $\mathrm{dAl}$ supply. The resulting flux of $\mathrm{dAl}$ ranged from 2.15 to $37.15 \mathrm{nmolm}^{-2} \mathrm{~d}^{-1}$ (upward) and from -0.84 to $-1895 \mathrm{nmol} \mathrm{m}^{-2} \mathrm{~d}^{-1}$ (downward) with a significant downward flux associated with station 5 on the Greenland Shelf. The cruise median flux was upward and equivalent to $2.2 \mathrm{nmol} \mathrm{m}^{-2} \mathrm{~d}^{-1}$, which equated to $0.01 \%$ of the mixed layer dAl content. Separate consideration of the upward and downward fluxes revealed a median upward flux of $8 \mathrm{nmolm}^{-2} \mathrm{~d}^{-1}$ (0.05\% of mixed layer inventory) that almost equalled the median downward flux of $-8.9 \mathrm{nmol} \mathrm{m}^{-2} \mathrm{~d}^{-1}$ ( $-0.05 \%$ of mixed layer inventory).

\subsection{Seasonal nutrient demand and annual new production}

Our analysis of nutrient data from the two cruises conducted in April and August 2010 indicated that surface nutrient concentrations were substantially reduced during the intervening period in response to phytoplankton demand. Surface $\mathrm{NO}_{3}^{-}$concentrations were reduced by up to $12 \mu \mathrm{mol} \mathrm{L}^{-1}$ in the Irminger Basin and by $<10 \mu \mathrm{mol} \mathrm{L}^{-1}$ elsewhere. We calculated total nutrient drawdown of between 15.6 and $409.1 \mathrm{mmol} \mathrm{m}^{-2}$ for $\mathrm{NO}_{3}^{-}$, of between 5.5 and $166.2 \mathrm{mmol} \mathrm{m}^{-2}$ for $\mathrm{Si}(\mathrm{OH})_{4}$ and between 7.7 to 


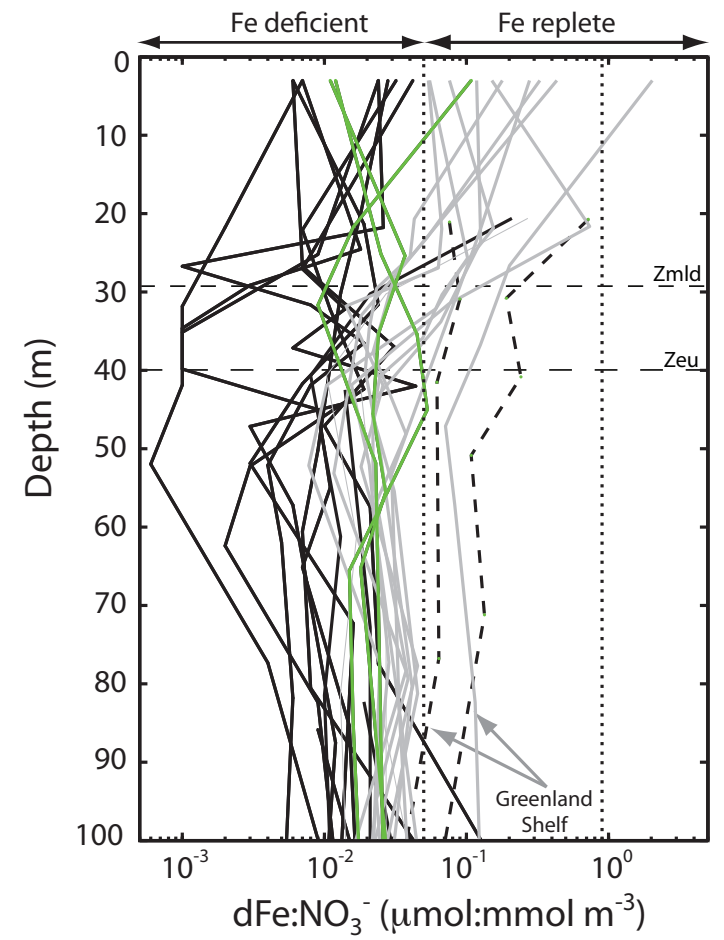

Fig. 7. Vertical profiles of the $\mathrm{dFe}: \mathrm{NO}_{3}^{-}$ratio over the upper $100 \mathrm{~m}$ of the water column for the stations shown in Fig. 1. Profiles from the Iceland Basin are plotted in grey, the Irminger Basin shown in black and stations approaching the Greenland Shelf (extreme western Irminger Basin) in green. Greenland Shelf profiles are indicated by black dashed lines and text labels. The vertical dotted lines indicate phytoplankton cellular $\mathrm{dFe} \mathrm{NO}_{3}^{-}$ratios under Fe replete conditions (Sunda and Huntsman, 1995; Ho et al., 2003; Twining et al., 2004). The horizontal dashed lines represent the cruise mean Zmld and the cruise mean Zeu.

$34.6 \mathrm{mmol} \mathrm{m}^{-2}$ for $\mathrm{PO}_{4}^{3-}$ (Fig. 5). The time period between observations ranged from 67 to $93 \mathrm{~d}$ and by using the appropriate temporal difference we obtained net estimates of daily $\mathrm{NO}_{3}^{-}$uptake of between $0.2-4.76 \mathrm{mmol} \mathrm{m}^{-2} \mathrm{~d}^{-1}$, $\mathrm{Si}(\mathrm{OH})_{4}$ uptake of $0.07-1.93 \mathrm{mmol} \mathrm{m}^{-2} \mathrm{~d}^{-1}$ and $\mathrm{PO}_{4}^{3-}$ uptake of $0.1-0.4 \mathrm{mmol} \mathrm{m}^{-2} \mathrm{~d}^{-1}$. Our upper estimate of daily $\mathrm{NO}_{3}^{-}$uptake of $4.76 \mathrm{mmol} \mathrm{m}^{-2} \mathrm{~d}^{-1}$ was broadly comparable to the estimate obtained by Sambrotto et al. (1993) of $5.43 \mathrm{mmol} \mathrm{m}^{-2} \mathrm{~d}^{-1}$, and the range in daily $\mathrm{NO}_{3}^{-}$uptake rates was also comparable to rates of $\mathrm{NO}_{3}^{-}$uptake that were obtained from the extrapolation of direct sea surface measurements (Table 1) across the mixed layer of between 1.1 and $7.3 \mathrm{mmol} \mathrm{NO}_{3}^{-} \mathrm{m}^{-2} \mathrm{~d}^{-1}$. Application of the Redfield $\mathrm{C}: \mathrm{N}$ ratio to the $\mathrm{NO}_{3}^{-}$drawdown rates produced daily new production estimates of between 0.02 and $0.38 \mathrm{~g} \mathrm{C} \mathrm{m}^{-2} \mathrm{~d}^{-1}$, with an average of $0.19 \pm 0.12 \mathrm{~g} \mathrm{C} \mathrm{m}^{-2} \mathrm{~d}^{-1}$. These estimates of new production were equivalent to between 5 and $17 \%$ of total primary production rates obtained by integrating sea surface measurements (Table 1) over the mixed layer.
The mean annual productive period in the North Atlantic subpolar gyre has been shown to last from April to $\mathrm{Au}-$ gust (Sanders et al., 2005; Henson et al., 2006). Under this assumption mean annual new production within the mixed layer of the subpolar gyre for 2010 would equate to $25 \pm 18 \mathrm{~g} \mathrm{~m}^{-2} \mathrm{yr}^{-1}$, somewhat lower than previous estimates of between 35 and $60 \mathrm{~g} \mathrm{C} \mathrm{m}^{-2} \mathrm{yr}^{-1}$ (Henson et al., 2003; Sanders et al., 2005; Waniek et al., 2005). Our reduced estimate of annual new production results from use of the mixed layer as the depth of calculation. When this exercise is repeated to $100 \mathrm{~m}$ we obtain a mean annual new production estimate of $57 \mathrm{~g} \mathrm{C} \mathrm{m}^{-2} \mathrm{yr}^{-1}$ (Table 5; Supplement Fig. 2).

Though there is inevitably some uncertainty in these new production estimates as they are based on geographically separated stations sampled in April and August, broad temporal averaging over the intervening time period and stoichiometric conversion ratios, we note that our results are broadly similar to existing observations. Previous measurements of $\mathrm{NO}_{3}^{-}$uptake for the full euphotic zone of the Iceland Basin made in July-August 2007 (M. Lucas, unpublished data), revealed integrated uptake rates of 1.01$11.72 \mathrm{mmol} \mathrm{NO}_{3}^{-} \mathrm{m}^{-2} \mathrm{~d}^{-1}$, thus our calculations of $\mathrm{NO}_{3}^{-}$uptake are within the range of directly measured rates of $\mathrm{NO}_{3}^{-}$ uptake at this time of year.

The calculation of seasonal changes to mixed layer integrated $\mathrm{dAl}$ and $\mathrm{dFe}$ pools showed that during the time interval between cruises integrated dAl concentrations decreased by between 7.7 and $97.2 \mu \mathrm{mol} \mathrm{m}^{-2}$ (Fig. 5), equivalent to between 0.09 and $1.13 \mu \mathrm{mol} \mathrm{m} \mathrm{m}^{-2} \mathrm{~d}^{-1}$ (Table 5). The biological demand for $\mathrm{dAl}$ is considered minimal (Stoffyn, 1979), thus this seasonal removal is most likely due to a scavenging effect caused by sinking particulate material, particularly diatom frustules, out of the mixed layer and onto which Al has been adsorbed (Moran and Moore, 1988; Koning et al., 2007). Thus, the observed decrease in integrated $\mathrm{dAl}$ concentrations is a complex result that reflects both changes in atmospheric inputs (a major pathway of $\mathrm{Al}$ to the ocean) but also the scavenging role of sinking particles. The estimates of seasonal change in integrated $\mathrm{dFe}$ concentrations within the mixed layer revealed decreases of $0.86-17.37 \mu \mathrm{mol} \mathrm{m}{ }^{-2}$ but also apparent increases at four stations of 3.19-5.44 $\mu \mathrm{mol} \mathrm{m}^{-2}$ (Fig. 5). There was no geographical pattern behind the increases or decreases and unlike the macronutrients, which are predominately supplied from below, Fe can be resupplied from a number of sources. It is interesting that a similar pattern was not apparent in the dAl data, which suggests that the ambiguous seasonal change in $\mathrm{dFe}$ cannot be linked to the resupply of Fe from a single supply process (e.g. atmospheric input), and that individual stations may have been influenced to a greater or lesser extent by different supply mechanisms. The largest removal of $\mathrm{dFe}\left(17.37 \mu \mathrm{mol} \mathrm{dFe} \mathrm{m}^{-2}\right.$ equivalent to $0.2 \mu \mathrm{mol} \mathrm{dFe} \mathrm{m}^{-2} \mathrm{~d}^{-1}$ ) occurred on the Icelandic Shelf. The lowest removal rate of $\sim 0.9 \mu \mathrm{mol} \mathrm{dFe} \mathrm{m}^{-2}$ (equivalent 
Table 4. Mixed layer integrated standing stocks of micro- and macronutrients and the importance of the supply term (Table 3) relative to the standing pool size.

\begin{tabular}{|c|c|c|c|c|c|c|c|c|c|c|}
\hline Turbulence station & $\begin{array}{l}\int \mathrm{NO}_{3}^{-} \\
\left(\mathrm{mmolm}^{-2}\right)\end{array}$ & $\begin{array}{l}\text { Daily diffu- } \\
\text { sive supply } \\
\text { relative to } \\
\text { pool }(\%)\end{array}$ & $\begin{array}{l}\int \mathrm{PO}_{4}^{3-} \\
\left(\mathrm{mmolm}^{-2}\right)\end{array}$ & $\begin{array}{l}\text { Daily diffu- } \\
\text { sive supply } \\
\text { relative to } \\
\text { pool }(\%)\end{array}$ & $\begin{array}{l}\int \mathrm{Si}(\mathrm{OH})_{4} \\
\left(\mathrm{mmolm}^{-2}\right)\end{array}$ & $\begin{array}{l}\text { Daily diffu- } \\
\text { sive supply } \\
\text { relative to } \\
\text { pool }(\%)\end{array}$ & $\begin{array}{l}\int \mathrm{dFe} \\
\left(\mu \mathrm{molm}{ }^{-2}\right)\end{array}$ & $\begin{array}{l}\text { Daily diffu- } \\
\text { sive supply } \\
\text { relative to } \\
\text { pool }(\%)\end{array}$ & $\begin{array}{l}\int \mathrm{dAl} \\
\left(\mu \mathrm{molm}^{-2}\right)\end{array}$ & $\begin{array}{l}\text { Daily diffu- } \\
\text { sive supply } \\
\text { relative to } \\
\text { pool (\%) }\end{array}$ \\
\hline 1 & 84.72 & 0.28 & 5.12 & 0.27 & 43.41 & 0.18 & 6.03 & 0.06 & 25.59 & 0.13 \\
\hline 2 & 117.46 & 0.14 & 9.21 & 0.09 & 53.10 & 0.12 & 4.90 & 0.12 & 27.45 & 0.12 \\
\hline 3 & 309.85 & 0.21 & 25.84 & 0.18 & 184.40 & 0.09 & 4.84 & -0.01 & 30.20 & -0.02 \\
\hline 4 & 255.41 & 0.05 & 21.17 & 0.03 & 167.62 & 0.03 & 6.52 & 0.02 & 20.00 & 0.19 \\
\hline 5 & 4.26 & 3.87 & 2.02 & 1.73 & 6.88 & 0.88 & 17.99 & -1.02 & 139.57 & -1.36 \\
\hline 6 & 91.20 & 0.43 & 7.23 & 0.28 & 41.35 & 0.31 & 0.57 & 0.55 & 28.18 & -0.09 \\
\hline 7 & 132.26 & 0.13 & 10.16 & 0.09 & 59.35 & 0.09 & 1.82 & 0.31 & 24.50 & 0.07 \\
\hline 8 & 56.37 & 0.06 & 6.48 & 0.04 & 43.49 & 0.01 & 0.86 & -0.05 & 11.16 & 0.07 \\
\hline 9 & 120.32 & 0.05 & 10.61 & 0.03 & 70.61 & 0.03 & 1.46 & 0.16 & 14.61 & 0.02 \\
\hline 10 & 142.58 & 0.09 & 11.43 & 0.05 & 81.43 & 0.05 & 2.01 & 1.05 & 22.79 & -0.03 \\
\hline 11 & 187.75 & 0.09 & 13.02 & 0.07 & 72.31 & 0.06 & 2.50 & -0.41 & 9.81 & -0.03 \\
\hline 12 & 186.34 & 0.02 & 14.06 & 0.03 & 68.83 & 0.04 & 0.68 & -0.02 & 16.03 & 0.05 \\
\hline 13 & 100.95 & 0.13 & 5.07 & 0.14 & 29.50 & 0.09 & 1.64 & 0.01 & 15.14 & -0.06 \\
\hline 14 & 16.82 & 1.51 & 2.63 & 0.70 & 30.50 & 0.06 & 0.75 & 0.09 & 33.55 & 0.02 \\
\hline 15 & 34.88 & 0.76 & 4.40 & 0.33 & 35.34 & 0.12 & 2.56 & -0.04 & 25.75 & 0.01 \\
\hline 16 & 43.74 & 0.05 & 4.02 & 0.03 & 18.62 & 0.02 & 16.93 & 0.00 & 30.10 & 0.00 \\
\hline 17 & 34.73 & 0.39 & 3.00 & 0.15 & 18.99 & 0.08 & 4.06 & -0.10 & 18.63 & 0.08 \\
\hline 18 & 33.95 & 0.43 & 3.98 & 0.24 & 30.42 & 0.06 & 5.07 & -0.01 & 23.61 & -0.04 \\
\hline 19 & 85.76 & 0.06 & 6.29 & 0.04 & 44.92 & 0.02 & - & - & 17.60 & 0.01 \\
\hline 20 & 83.76 & 0.35 & 6.77 & 0.30 & 37.62 & 0.24 & - & - & 26.96 & -0.18 \\
\hline 21 & 12.20 & 0.16 & 7.34 & 0.09 & 9.17 & 0.10 & 4.06 & -0.07 & 22.97 & 0.01 \\
\hline Median & 85.8 & 0.14 & 6.8 & 0.09 & 43.4 & 0.08 & 2.56 & 0.001 & 23.61 & 0.01 \\
\hline Median up & - & - & - & - & - & - & - & 0.1 & - & 0.05 \\
\hline Median down & - & - & - & - & - & - & - & -0.05 & - & -0.05 \\
\hline
\end{tabular}

to $\sim 0.01 \mu \mathrm{mol} \mathrm{dFe} \mathrm{m}^{-2} \mathrm{~d}^{-1}$ ) was found within the central Irminger Basin. However the largest increases in integrated $\mathrm{dFe}$ of 4.4 and $5.4 \mu \mathrm{mol} \mathrm{dFe} \mathrm{m}^{-2}$ were also found at stations within the Irminger Basin but closer to the Reykjanes Ridge suggesting that supply and removal of Fe is significantly nonlinear.

Despite widespread acceptance of the atmosphere as the major transport route for $\mathrm{Fe}$ to the ocean we also identified a major reorganisation of the near-surface water column between the two cruises within the Irminger Basin (Fig. 6). This led to the introduction of a warmer and fresher water mass into the basin, which has been linked to changes in large-scale atmospheric forcing by the North Atlantic Oscillation (Henson et al., 2013). This hydrographic change is linked to subsurface changes in the concentration of all nutrients, which will inevitably affect the drawdown estimates we describe above (particularly comparison B in Fig. 5, which shows an increase), but these differences are difficult to isolate from differences due to phytoplankton uptake and/or atmospheric resupply. Nevertheless, this hydrographic influence also provides additional complexity for the interpretation of seasonal changes.

\subsection{Biological relevance of diffusive nutrient supply}

The comparison of integrated macro and trace nutrient inventories with the diffusive nutrient fluxes demonstrated that the daily diffusive fluxes were of minor importance for the re- supply of nutrients to the surface ocean (Table 4). However a more appropriate comparison would be to actual rates of biological uptake, which may be dwarfed by the magnitude of standing pools. To make this comparison we have used the seasonal estimates of nutrient and $\mathrm{dFe}$ drawdown to derive approximate in situ daily uptake rates (Table 5). When compared in this manner the daily diffusive fluxes of $\mathrm{NO}_{3}^{-}$, $\mathrm{Si}(\mathrm{OH})_{4}$ and $\mathrm{PO}_{4}^{3-}$ at the base of the mixed layer equate on average to $5 \pm 2 \%, 5 \pm 3 \%$ and $3 \pm 1 \%$ of daily phytoplankton uptake respectively; still relatively small but now at least an order of magnitude larger than when compared to the in situ pools. Similar calculations for Fe are more complicated due to the resupply of Fe between sampling periods at a number of stations (Fig. 5) but the mean seasonally derived uptake rate of $\sim 0.01 \mu \mathrm{mol} \mathrm{m} \mathrm{m}^{-2} \mathrm{~d}^{-1}$ indicates that a diffusive supply of $2.76 \mathrm{nmolm}^{-2} \mathrm{~d}^{-1}$ could potentially supply $28 \%$ of the in situ demand for Fe. However, this result must be viewed cautiously due to the approximations underlying this calculation.

\subsection{Winter convective nutrient supply}

Winter convective mixing is considered the dominant nutrient supply process and it is useful to provide an estimate of its magnitude for context. Examination of individual density profiles from Argo floats that were active within the Irminger and Iceland Basins during winter 2010 and applying the de Boyer-Montegut et al. (2004) criteria for estimating 
Table 5. Phytoplankton daily nutrient demand and annual new production rates as determined in this study over (a) the mixed layer and (b) the upper $100 \mathrm{~m}$ of the water column. The comparison to $100 \mathrm{~m}$ is used to provide an absolute estimate of seasonal nutrient demand that removes ambiguities due to seasonal differences in mixed layer and euphotic zone depths. New production rates are estimated from the nitrate drawdown rate, application of a $\mathrm{C}: \mathrm{N}$ ratio of 6.6 and scaled by the length of the productive period (from April to August).

\begin{tabular}{|c|c|c|c|c|c|c|c|}
\hline \multicolumn{8}{|c|}{ (a) Mixed layer } \\
\hline Comparison & $\begin{array}{l}\text { Time inter- } \\
\text { val (days) }\end{array}$ & $\begin{array}{l}\text { Nitrate } \\
\text { demand } \\
\left(\mathrm{mmolm}^{-2} \mathrm{~d}^{-1}\right)\end{array}$ & $\begin{array}{l}\text { Silicate } \\
\text { demand } \\
\left(\mathrm{mmolm}^{-2} \mathrm{~d}^{-1}\right)\end{array}$ & $\begin{array}{l}\text { Phosphate } \\
\text { demand } \\
\left(\mathrm{mmolm}^{-2} \mathrm{~d}^{-1}\right)\end{array}$ & $\begin{array}{l}\text { Annual new } \\
\text { production } \\
\left(\mathrm{gCm}^{-2} \mathrm{yr}^{-1}\right)\end{array}$ & $\begin{array}{l}\text { dFe demand } \\
\left(\mu \mathrm{molm}{ }^{-2} \mathrm{~d}^{-1}\right)\end{array}$ & $\begin{array}{l}\text { dAl demand } \\
\left(\mu \mathrm{molm} \mathrm{m}^{-2} \mathrm{~d}^{-1}\right)\end{array}$ \\
\hline A & 77 & 0.20 & -0.09 & - & 2.47 & - & - \\
\hline B & 78 & -0.65 & -1.06 & -0.18 & -7.91 & -0.04 & 0.10 \\
\hline $\mathrm{C}$ & 78 & 3.08 & 0.07 & 0.10 & 37.52 & 0.01 & 0.77 \\
\hline $\mathrm{D}$ & 83 & 3.59 & 1.14 & 0.36 & 43.80 & 0.01 & 0.09 \\
\hline $\mathrm{E}$ & 73 & 2.91 & 1.06 & - & 35.51 & -0.07 & 0.79 \\
\hline $\mathrm{F}$ & 72 & 1.69 & 0.84 & - & 20.58 & -0.06 & 1.03 \\
\hline $\mathrm{G}$ & 80 & 0.94 & 0.10 & - & 11.52 & -0.05 & -0.01 \\
\hline $\mathrm{H}$ & 78 & 1.86 & 0.83 & 0.23 & 22.68 & 0.05 & 0.40 \\
\hline I & 86 & 4.76 & 1.93 & 0.40 & 58.02 & 0.20 & 1.13 \\
\hline Mean \pm 1 SD & 78 & $2.04 \pm 1.49$ & $0.54 \pm 0.68$ & $0.18 \pm 0.14$ & $24.91 \pm 18.11$ & $0.01 \pm 0.09$ & $0.54 \pm 0.45$ \\
\hline
\end{tabular}

\begin{tabular}{|c|c|c|c|c|c|c|c|}
\hline \multicolumn{8}{|l|}{ (b) $100 \mathrm{~m}$} \\
\hline Comparison & $\begin{array}{l}\text { Time inter- } \\
\text { val (days) }\end{array}$ & $\begin{array}{l}\text { Nitrate } \\
\text { demand } \\
\left(\mathrm{mmolm}^{-2} \mathrm{~d}^{-1}\right)\end{array}$ & $\begin{array}{l}\text { Silicate } \\
\text { demand } \\
\left(\mathrm{mmolm}^{-2} \mathrm{~d}^{-1}\right)\end{array}$ & $\begin{array}{l}\text { Phosphate } \\
\text { demand } \\
\left(\mathrm{mmolm}^{-2} \mathrm{~d}^{-1}\right)\end{array}$ & $\begin{array}{l}\text { Annual new } \\
\text { production } \\
\left(\mathrm{gCm}^{-2} \mathrm{yr}^{-1}\right)\end{array}$ & $\begin{array}{l}\mathrm{dFe} \text { demand } \\
\left(\mu \mathrm{molm} \mathrm{m}^{-2} \mathrm{~d}^{-1}\right)\end{array}$ & $\begin{array}{l}\text { dAl demand } \\
\left(\mu \mathrm{mol} \mathrm{m}{ }^{-2} \mathrm{~d}^{-1}\right)\end{array}$ \\
\hline A & 77 & 3.47 & 1.78 & - & 42.35 & - & - \\
\hline B & 78 & 6.45 & 1.56 & 0.29 & 78.64 & -0.07 & 2.31 \\
\hline $\mathrm{C}$ & 78 & 5.12 & 0.18 & 0.26 & 62.41 & 0.26 & 5.85 \\
\hline D & 83 & 3.39 & 0.88 & 0.39 & 41.39 & 0.11 & 1.05 \\
\hline $\mathrm{E}$ & 73 & 5.95 & 2.75 & - & 72.55 & -0.07 & 2.56 \\
\hline $\mathrm{F}$ & 72 & 5.35 & 3.24 & - & 65.20 & -0.16 & 6.07 \\
\hline G & 80 & 3.71 & 2.38 & - & 45.22 & -0.02 & 3.57 \\
\hline $\mathrm{H}$ & 78 & 3.25 & 0.74 & - & 39.63 & -0.25 & 1.73 \\
\hline I & 86 & 5.16 & 3.41 & 0.37 & 62.91 & 0.59 & 1.71 \\
\hline Mean & 78 & $4.65 \pm 1.21$ & $1.88 \pm 1.15$ & $0.33 \pm 0.06$ & $56.7 \pm 14.8$ & $0.11 \pm 0.25$ & $3.11 \pm 1.9$ \\
\hline
\end{tabular}

mixed layer depth indicated that winter mixing for 2010 was shallower than the climatological average. Indeed, for the Irminger Basin the average maximum depth of winter mixing appears only to have reached $170 \pm 100 \mathrm{~m}$, whilst for the Iceland Basin the average depth of winter mixing was $355 \pm 144 \mathrm{~m}$. In both basins individual mixed layer estimates in excess of $400 \mathrm{~m}$ were observed suggesting spatially variable depths of convective mixing but in general mixing was relatively shallow. In contrast, the Argo based mixed layer depth climatology of Hosoda et al. (2010) indicates average maximum winter mixed layer depths of $414 \pm 70 \mathrm{~m}$ for the Irminger Basin and $437 \pm 66 \mathrm{~m}$ for the Iceland Basin. In accordance with the shallower winter mixing depths we based the following calculations on a winter mixed layer depth of $200 \mathrm{~m}$ for the Irminger Basin and of $350 \mathrm{~m}$ for the Iceland Basin. We note that these mixed layer depths are shallower than would perhaps be expected from the climatological average and that the patchy distribution of Argo float profiles in both basins during winter 2010 is likely to have introduced a degree of spatial bias whereby deeper but spatially localised mixing may have been missed. Nevertheless winter 2010 does appear to have been characterised by relatively shallow convective mixing and hence is likely to have resulted in lower than normal nutrient input.

The average nutrient concentrations at a depth of $200 \mathrm{~m}$ in the Irminger Basin as sampled in April 2010 were $15.5 \mu \mathrm{mol} \mathrm{NO}-\mathrm{L}^{-1}$, $0.85 \mu \mathrm{mol} \mathrm{PO}{ }_{4}^{3-} \mathrm{L}^{-1}, 7 \mu \mathrm{mol} \mathrm{Si}(\mathrm{OH})_{4} \mathrm{~L}^{-1}, 2.9 \mathrm{nmol} \mathrm{dAl} \mathrm{L}^{-1}$ and $0.2 \mathrm{nmoldFe} \mathrm{L}{ }^{-1}$. Assuming homogenous mixing to $200 \mathrm{~m}$ and a typical euphotic zone depth of $50 \mathrm{~m}$, we calculate that convective mixing in winter 2010 could have supplied $0.78 \mathrm{~mol} \mathrm{NO}_{3}^{-} \mathrm{m}^{-2} \mathrm{yr}^{-1}, 0.04 \mathrm{~mol} \mathrm{PO}_{4}^{3-} \mathrm{m}^{-2} \mathrm{yr}^{-1}$, $0.35 \mathrm{~mol} \mathrm{Si}(\mathrm{OH})_{4} \mathrm{~m}^{-2} \mathrm{yr}^{-1}, \quad 145 \mu \mathrm{mol} \mathrm{dAl} \mathrm{m} \mathrm{yr}^{-1}$, and $10 \mu \mathrm{mol} \mathrm{dFe} \mathrm{m}{ }^{-2} \mathrm{yr}^{-1}$ to the euphotic zone of the Irminger Basin.

Surprisingly, despite deeper winter mixing to $350 \mathrm{~m}$ in the Iceland Basin similar nutrient concentrations were found at this depth to those in the Irminger Basin. Average nutrient concentrations at $350 \mathrm{~m}$ in the Iceland Basin were $13.75 \mu \mathrm{mol} \mathrm{NO}_{3}^{-} \mathrm{L}^{-1}, 0.8 \mu \mathrm{mol}$ $\mathrm{PO}_{4}^{3-} \mathrm{L}^{-1}, \quad 6 \mu \mathrm{molSi}(\mathrm{OH})_{4} \mathrm{~L}^{-1}, \quad 5.5 \mathrm{nmol} \mathrm{dAl} \mathrm{L} \mathrm{L}^{-1}$ and $0.75 \mathrm{nmol} \mathrm{dFe} \mathrm{L}^{-1}$. Using the same approach as before winter convective mixing supplied $0.69 \mathrm{~mol} \mathrm{NO}_{3}^{-} \mathrm{m}^{-2} \mathrm{yr}^{-1}$, $0.04 \mathrm{~mol} \mathrm{PO}_{4}^{3-} \mathrm{m}^{-2} \mathrm{yr}^{-1}, \quad 0.3 \mathrm{~mol} \mathrm{Si}(\mathrm{OH})_{4} \mathrm{~m}^{-2} \quad \mathrm{yr}^{-1}$, 
$275 \mu \mathrm{mol} \mathrm{dAl} \mathrm{m}{ }^{-2} \mathrm{yr}^{-1}$, and $37.5 \mu \mathrm{mol} \mathrm{dFe} \mathrm{m}^{-2} \mathrm{yr}^{-1}$ to the euphotic zone of the Iceland Basin.

Based on the representative annual diffusive flux of $\mathrm{dFe}$ calculated above (Sect. 3.5) we estimate that in 2010 the winter convective supply of Fe to the Iceland Basin was over 59-fold larger than the annual diffusive flux. In the Irminger Basin the convective supply was 22 -fold larger than the annual diffusive supply. In both basins the diffusive flux was therefore a minor supply term.

\subsection{Atmospheric supply}

The dry deposition flux of Fe ranged between $2.2 \pm 0.9$ and $10.8 \pm 1.1 \mathrm{nmol} \mathrm{Fe} \mathrm{m}^{-2} \mathrm{~d}^{-1}$, whereas the dry deposition of Al ranged from $27.2 \pm 3.3$ to $445.2 \pm 3.4 \mathrm{nmol} \mathrm{Al} \mathrm{m}^{-2} \mathrm{~d}^{-1}$ (Table 6). Wet deposition fluxes were calculated based on mean (and range) aerosol concentrations and determined to be $3.4(1.7-6.0) \mathrm{nmol} \mathrm{m}^{-2} \mathrm{~d}^{-1}$ for soluble $\mathrm{Fe}$ and 73 (20180) $\mathrm{nmolm}^{-2} \mathrm{~d}^{-1}$ for soluble Al. These estimates are similar in magnitude to the calculated dry deposition fluxes for these species, although both estimates are subject to considerable uncertainty.

\section{Discussion}

\subsection{Significance of diffusive nutrient supplies}

We have demonstrated that the vertical daily diffusive flux of macronutrients into the mixed layer is a small source term in the subpolar North Atlantic Ocean typically representing $<0.5 \%$ of mixed layer standing stocks. This was partly due to the relative abundance of residual nutrient concentrations at the end of summer despite strong seasonal demand for those same nutrients by the resident phytoplankton population. Only at station 5 (Greenland Shelf) were the daily diffusive fluxes substantially larger and in the case of $\mathrm{NO}_{3}^{-}$equivalent to $4 \%$ of the integrated mixed layer standing stock. In this instance however the increase in the proportion of $\mathrm{NO}_{3}^{-}$ supplied by turbulent diffusion was the result of a modest increase in turbulent diffusivity compared to other stations coupled with a shoaling mixed layer and a lower mixed layer $\mathrm{NO}_{3}^{-}$inventory. The Greenland Shelf station was thus quite distinct and was not representative of the wider subpolar region.

Against a background of strong zonal nutrient gradients and relatively high integrated nutrient concentrations, the vertical daily diffusive flux of both macro and trace nutrients represented an insignificant supply term. Relative to our estimates of average daily phytoplankton demand however the diffusive fluxes appeared more important but still represented $<10 \%$ of phytoplankton demand, leading to the conclusion that nowhere did the diffusive supply of $\mathrm{dFe}$ or $\mathrm{NO}_{3}^{-}$ become highly significant during the summer. More fundamentally however, there is no reason to assume the diffusive flux would be preferentially assimilated over the in situ standing stock unless the diffusive supply were in some way more bioavailable, perhaps, in the case of $\mathrm{dFe}$, as a result of differing mixtures of aqueous and colloidal species. Thus, we can only conclude that the turbulent diffusive flux of nutrients plays only a very minor role in both the nutrient budget of the subpolar gyre and in the seasonal productivity of the region. A similar lack of significance in the ability of the diffusive $\mathrm{dFe}$ supply to alleviate Fe limitation was also identified by Croot et al. (2007) within the Fe limited surface waters of the Southern Ocean suggesting that even in chronically $\mathrm{Fe}$ limited systems the diffusive supply is of minor relevance. Why might this be?

Estimates of aeolian dust input to the subpolar North Atlantic vary but may reach levels of order $\sim 1 \mathrm{~g} \mathrm{~m}^{-2} \mathrm{yr}^{-1}$ in some areas (Jickells et al., 2005). A corresponding Fe input of $\sim 0.04 \mathrm{~g} \mathrm{Fe} \mathrm{m}^{-2} \mathrm{yr}^{-1}$ was subsequently calculated by Mahowald et al. (2009). We estimate, using a dust Fe content of $3.5 \%$ (the mean continental crust Fe content), that dust input of $1 \mathrm{~g} \mathrm{~m}^{-2} \mathrm{yr}^{-1}$ could provide $\sim 1700 \mathrm{nmol} \mathrm{Fe} \mathrm{m} \mathrm{m}^{-2} \mathrm{~d}^{-1}$ to the subpolar North Atlantic if the entire dust Fe content were to become available. However, Fe solubility rates following aeolian input are highly variable and poorly constrained (Boyd et al., 2009; Mahowald et al., 2009; Baker and Croot, 2010). Using the lower solubility rate of $0.4 \%$ discussed by Mahowald et al. (2009) the soluble Fe flux from $1 \mathrm{~g}$ of dust $\mathrm{m}^{-2} \mathrm{yr}^{-1}$ would equate to just $6.9 \mathrm{nmol} \mathrm{Fe} \mathrm{m}^{-2} \mathrm{~d}^{-1}$. This estimate is similar to the mean dry Fe deposition flux of $5.9 \mathrm{nmol} \mathrm{Fe} \mathrm{m}^{-2} \mathrm{~d}^{-1}$ measured during the cruise (Table 6) suggesting that modelled estimates of aeolian $\mathrm{Fe}$ input are in reasonable agreement with observations. Interestingly, the measured dry atmospheric Fe input was comparable in magnitude to the mean upward diffusive flux of Fe measured in this study but both were small relative to the integrated pool of $\mathrm{dFe}$ in the surface mixed layer. Whilst it is likely that additional Fe supply mechanisms were active in this area (e.g. lateral mesoscale fluxes), the relative availability of $\mathrm{dFe}$ in summer 2010, despite previous reports of Fe limitation (Nielsdottir et al., 2009), suggests such limitation is either episodic or more likely a function of the bioavailability of the $\mathrm{dFe}$ pool.

Biological Fe uptake rates measured during this cruise using ${ }^{55} \mathrm{Fe}$ were $\sim 0.37 \pm 0.29 \mathrm{pmol} \mathrm{L}^{-1} \mathrm{~h}^{-1}$ (C. M. Moore, unpublished data). Extrapolated over a $30 \mathrm{~m}$ mixed layer this would equate to an integrated $\mathrm{Fe}$ uptake of $\sim 0.3 \mu \mathrm{mol} \mathrm{m} \mathrm{m}^{-2} \mathrm{~d}^{-1}$, approximately 30 times larger than the seasonally derived mean daily estimate (Table 5), and implies that a diffusive supply to the mixed layer of $2.76 \mathrm{nmol} \mathrm{Fe} \mathrm{m}^{-2} \mathrm{~d}^{-1}$ (Table 3) would represent $\sim 1 \%$ of daily phytoplankton Fe demand. This is far smaller than the estimate of $\sim 28 \%$ derived from the seasonal rate of $\mathrm{Fe}$ removal calculated above but probably more accurate as the seasonally derived estimate is susceptible to a number of errors including the resupply of $\mathrm{Fe}$ to the surface ocean between sampling periods. This comparison to in situ Fe uptake rates further supports the conclusions presented here that 
Table 6. Atmospheric deposition rates of $\mathrm{Fe}$ and $\mathrm{Al}$ during summer 2010. Please note that the presented latitude and longitude are based on the midpoint of each sampling period.

\begin{tabular}{|c|c|c|c|c|c|c|c|c|c|}
\hline Station & Date & $\begin{array}{l}\text { Mid } \\
\text { lat. }\left({ }^{\circ} \mathrm{N}\right)\end{array}$ & $\begin{array}{l}\text { Mid } \\
\text { long. } \\
\left({ }^{\circ} \mathrm{W}\right)\end{array}$ & $\begin{array}{l}\text { Aerosol soluble Fe con- } \\
\text { centration } \\
<1 \mu \mathrm{m} \\
\left(\mathrm{pmolm}^{-3}\right)\end{array}$ & $\begin{array}{l}\text { Aerosol soluble Fe con- } \\
\text { centration } \\
>1 \mu \mathrm{m} \text { or total } \\
\left(\mathrm{pmol} \mathrm{m}^{-3}\right)\end{array}$ & $\begin{array}{l}\text { Dry Fe deposition } \\
\left(\mathrm{nmol} \mathrm{m}^{-2} \mathrm{~d}^{-1}\right)\end{array}$ & $\begin{array}{l}\text { Aerosol soluble Al con- } \\
\text { centration } \\
<1 \mu \mathrm{m} \\
\left(\mathrm{pmolm}^{-3}\right)\end{array}$ & $\begin{array}{l}\text { Aerosol soluble } \mathrm{Al} \text { con- } \\
\text { centration } \\
>1 \mu \mathrm{m} \text { or total } \\
\left(\mathrm{pmol} \mathrm{m}^{-3}\right)\end{array}$ & $\begin{array}{l}\text { Dry } \mathrm{Al} \text { deposi- } \\
\text { tion } \\
\left(\mathrm{nmolm}^{-2} \mathrm{~d}^{-1}\right)\end{array}$ \\
\hline M07 & $18 \mathrm{Jul} 2010$ & 60.00 & -38.59 & $3.7 \pm 0.5$ & $2.1 \pm 1$ & $2.2 \pm 0.9^{\mathrm{a}}$ & $30.2 \pm 2.7$ & $28.4 \pm 3.6$ & $27.2 \pm 3.3^{\mathrm{a}}$ \\
\hline M08 & $20 \mathrm{Jul} 2010$ & 60.72 & -38.49 & $3.2 \pm 1.1$ & $6.1 \pm 1.5$ & $5.6 \pm 1.4^{\mathrm{a}}$ & $23.4 \pm 6.9$ & $67.9 \pm 6.5$ & $60.7 \pm 6.2^{\mathrm{a}}$ \\
\hline M09 & $24 \mathrm{Jul} 2010$ & 61.19 & -32.98 & $2 \pm 0.3$ & $2.9 \pm 0.5$ & $2.7 \pm 0.5^{\mathrm{a}}$ & $30.5 \pm 3.3$ & $512.2 \pm 3.6$ & $445.2 \pm 3.4^{\mathrm{a}}$ \\
\hline M10 & 27 Jul 2010 & 59.42 & -33.40 & $6.3 \pm 2.4$ & $11.8 \pm 1$ & $10.8 \pm 1.1^{\mathrm{a}}$ & $96.3 \pm 3.4$ & $188.8 \pm 4.7$ & $171.4 \pm 4.4^{\mathrm{a}}$ \\
\hline M11 & 31 Aug 2010 & 63.41 & -29.43 & $5 \pm 1.1$ & $10 \pm 0.7$ & $9.0 \pm 0.7^{\mathrm{a}}$ & - & - & - \\
\hline M12 & 5 Aug 2010 & 61.18 & -22.42 & $4.2 \pm 1.8$ & $6.5 \pm 0.6$ & $5.9 \pm 0.7^{\mathrm{a}}$ & $45.2 \pm 1.9$ & $82.2 \pm 4$ & $74.9 \pm 3.6^{\mathrm{a}}$ \\
\hline
\end{tabular}

a Dry deposition rates calculated assuming depositional velocities of $1 \mathrm{cms}^{-1}$ for the coarse aerosol fraction $(>1 \mu \mathrm{m})$ and $0.1 \mathrm{cms} \mathrm{s}^{-1}$ for the fine aerosol fraction $(<1 \mu \mathrm{m})$.

only low significance can be ascribed to the diapycnal $\mathrm{dFe}$ supply.

\subsection{Stoichiometry of diffusive nutrient supplies}

A key determinant for assessing the significance of diffusive nutrient supplies is not just the magnitude of any diffusive nutrient flux but also the ratio of the nutrients supplied, as it is this latter term that will ultimately allow for complete utilisation. Despite some variability between stations the average $\mathrm{N}: \mathrm{P}$ ratio of the daily diffusive flux to the mixed layer was $16: 1$, whereas the average $\mathrm{N}: \mathrm{Si}$ ratio was $4.6: 1$. The diffusive macronutrient supply therefore was generally at or above the stoichiometries expected for balanced phytoplankton growth and there is no indication that this would have impeded complete utilisation by phytoplankton under idealised conditions. However, surface N : P ratios (Fig. 2) indicated widespread variability which must have resulted from some additional factor (or factors) impacting the drawdown of nutrients. The dFe : $\mathrm{NO}_{3}^{-}$ratio of the diffusive supply was highly variable between stations but averaged $0.03: 1$ $\mu \mathrm{mol}: \mathrm{mmol}$. This is lower than phytoplankton cellular Fe : N ratios found during phytoplankton growth under $\mathrm{Fe}$ replete conditions (dFe : $\mathrm{NO}_{3}^{-}$of $0.05-0.9 \mu \mathrm{mol}: \mathrm{mmol}$; Sunda and Huntsman, 1995; Ho et al., 2003) and indicates that in general the diffusive supply of dFe was insufficient for phytoplankton to utilise the diffusive supply of $\mathrm{NO}_{3}^{-}$.

Previously, Nielsdottir et al. (2009) noted that waters to depths of at least $1000 \mathrm{~m}$ in the Iceland Basin are characterised with a $\mathrm{dFe}: \mathrm{NO}_{3}^{-}$ratio that is less than the phytoplankton cellular Fe : $\mathrm{N}$ ratio (e.g. Twining et al., 2004). Our data covered a wider geographical region than reported by Nielsdottir et al., (2009) but showed similarly low $\mathrm{dFe}: \mathrm{NO}_{3}^{-}$ ratios in surface waters (Fig. 2). Profiles of the $\mathrm{dFe}^{-\mathrm{NO}_{3}^{-}}$ ratio to $100 \mathrm{~m}$ showed that low $\mathrm{dFe}: \mathrm{NO}_{3}^{-}$ratios were not simply restricted to the surface mixed layer (Fig. 7) and that a zonal trend of increased Fe deficiency (decreasing dFe : $\mathrm{NO}_{3}^{-}$ ratio) towards the west was evident. Only when the influence of Greenland was encountered did this trend reverse indicating the presence of a significant source of $\mathrm{dFe}$ to the water column from a terrestrial (e.g. glacial meltwater; Bhatia et al., 2013) or shallow marine source (e.g. shelf sediments; El- rod et al., 2004; Planquette et al., 2007), which did not extend far into the Irminger Basin as noted in similar studies (Johnson et al., 1997; Elrod et al., 2004). Between 20 and $40 \mathrm{~m}$ depth $\mathrm{dFe}: \mathrm{NO}_{3}^{-}$ratios increased, lending further support to the notion that rapid microbial recycling of $\mathrm{Fe}$ is an important aspect of the Fe cycle of the subpolar North Atlantic.

The widespread occurrence of low $\mathrm{dFe}: \mathrm{NO}_{3}^{-}$ratios in near surface waters indicated that regardless of the magnitude of the turbulent diffusive flux the source waters that resupply the surface ocean with $\mathrm{Fe}$ are inherently low in $\mathrm{dFe}$ relative to their $\mathrm{NO}_{3}^{-}$content so that complete consumption of macronutrients is unlikely. A similar observation presented by Croot et al. (2007) from the Southern Ocean suggests some simple parallels can be drawn between these two regions with regards to the importance of underlying source waters for Fe limitation in summer months. In particular the weak vertical $\mathrm{Fe}$ gradients typical of both regions minimises the importance of the diffusive Fe supply and promotes the relative importance of recycled sources of Fe for supporting in situ demand. Furthermore, the large-scale circulation of the North Atlantic subpolar gyre and of the water masses, particularly seasonally formed mode waters, that are found within the gyre may play a more fundamental role in the overall productivity of the gyre than has been previously appreciated as the quantity of Fe held within these waters, and which is accessed during winter mixing, may be a key control on productivity levels in subsequent years.

To test this we provide a preliminary assessment of the $\mathrm{dFe}: \mathrm{NO}_{3}^{-}$ratio of the convective supply based on the concentrations of $\mathrm{NO}_{3}^{-}$and $\mathrm{dFe}$ found at the maximum depth of convective winter mixing for 2010. We estimate the $\mathrm{dFe}: \mathrm{NO}_{3}^{-}$ratio of the convective supply to have been 0.019 and $0.039 \mu \mathrm{mol}: \mathrm{mmol} \mathrm{m}^{-3}$ for the Irminger and Iceland basins respectively. These estimates are comparable to the mean $\mathrm{dFe}: \mathrm{NO}_{3}^{-}$ratio in the diffusive supply of $0.03: 1$ $\mu \mathrm{mol}: \mathrm{mmol} \mathrm{m}^{-3}$, and suggests that there may only have been small differences in the supply ratio of $\mathrm{dFe}: \mathrm{NO}_{3}^{-}$during the convective period compared to what is supplied during the rest of the year via diffusion. However, it is worth noting that from the profile data shown in Fig. 7 a slightly higher mean $\mathrm{dFe}: \mathrm{NO}_{3}^{-}$ratio of $0.06 \mu \mathrm{mol}: \mathrm{mmol} \mathrm{m}^{-3}$ can be calculated for the upper $100 \mathrm{~m}$ of the water column. This 
ratio is heavily influenced by the input of $\mathrm{Fe}$ at the sea surface, and if the upper $30 \mathrm{~m}$ of observations are excluded (i.e. the mixed layer where the mean $\mathrm{dFe}: \mathrm{NO}_{3}^{-}$ratio is 0.13 $\mu \mathrm{mol}: \mathrm{mmol} \mathrm{m}^{-3}$ but also highly variable) the ratio reduces to $0.028 \mu \mathrm{mol}: \mathrm{mmol} \mathrm{m}^{-3}$, similar to the deep water values and comparable to the diffusive supply ratio. This near surface elevation in $\mathrm{dFe}: \mathrm{NO}_{3}^{-}$ratios suggests that input of Fe to the mixed layer, presumably from the atmosphere, can have an important role in increasing $\mathrm{dFe}: \mathrm{NO}_{3}^{-}$ratios and hence in increasing the likelihood of nutrient drawdown and in the alleviation of Fe limitation. The significance of the convective supply for summer productivity may therefore be rather small but this conclusion requires further investigation.

\subsection{Wider implications}

\subsubsection{Nutrient budgets}

The upward diffusive flux of $\mathrm{dAl}$ at several stations raises a number of interesting questions as $\mathrm{dAl}$ is widely used as a proxy for atmospheric dust input (e.g. Measures and Brown, 1996; Measures and Vink, 2000; Han et al., 2008). The diffusive reinjection of $\mathrm{dAl}$ into the surface mixed layer therefore may introduce complications into the current practise of using surface dAl concentrations to calculate dust input rates due to the possibility of double accounting. The recent synthesis of dAl observations by Han et al. (2008) reveals the limited observational data set that currently exists, thus whilst we cannot easily quantify the likely impact we would urge greater awareness of the effect that a net upward diffusive flux of dAl, particularly in remote ocean regions where observations of $\mathrm{dAl}$ are limited, has on derived dust fluxes.

In the Iceland Basin Forryan et al. (2012) demonstrated that the most important nutrient supply mechanism on an annual basis was winter convective mixing and that the turbulent diffusive supply of nutrients was of minor significance for productivity levels. Critically Forryan et al. (2012) demonstrated that the winter convective supply of Fe, which they estimated to be between 13 and $17 \mu \mathrm{mol} \mathrm{m}^{-2} \mathrm{yr}^{-1}$, was fully utilised during the spring bloom and the exhaustion of this Fe supply ultimately limited production during the remainder of the year. Recent observations of Fe stress developing during the North Atlantic spring bloom support this view (Ryan-Keogh et al., 2013). Our convective Fe supply estimates of $10 \mu \mathrm{mol} \mathrm{m}{ }^{-2} \mathrm{yr}^{-1}$ to the Irminger Basin and of $37.5 \mu \mathrm{mol} \mathrm{m}{ }^{-2} \mathrm{yr}^{-1}$ to the Iceland Basin are similar to those presented by Forryan et al. (2012) but highlight the importance of interannual variability in winter mixing depths for $\mathrm{Fe}$ supply. Furthermore, variability in the convective supply may be an important factor explaining interannual variability in the magnitude of the spring bloom across the subpolar gyre. Our broader spatial assessment of turbulent diffusive nutrient supply to the subpolar gyre complements and expands upon the previous observations reported by Forryan et al. (2012) and we estimate that convective winter mixing provided between 22- and 59-fold more Fe than the annual diapycnal diffusive flux in 2010.

\subsubsection{Are our results typical?}

With limited previous study in this region, particularly of $\mathrm{Fe}$ dynamics, it is difficult to constrain the representative nature of our observations though all indications are that our results complement and expand upon existing studies. More broadly our estimates of diffusive nutrient supply are very similar to rates obtained here and in other Fe limited regions. We have no reason therefore to think that our results are atypical. However, we note in passing the occurrence of an unusual background event, specifically the eruption of the Icelandic volcano Eyjafjallajökull in April and May 2010. Although the vertical diffusive flux of nutrients is entirely separate from any volcanic inputs, the possibility remains that surface ocean nutrient concentrations and potentially the subsurface nutrient gradients may have been influenced by the longer-term consequences of volcanic ash input to the surface ocean many of which are poorly understood (Duggen et al., 2010). However, even though surface nutrient conditions southwest of Iceland were lower in 2010 than reported in recent years (Achterberg et al., 2013), the overall significance of the diffusive supply was still low.

\section{Supplementary material related to this article is available online at http://www.biogeosciences.net/11/ 2113/2014/bg-11-2113-2014-supplement.pdf.}

Acknowledgements. We thank the officers and crew of the RRS Discovery for their excellent support during both cruises, and A. Poulton and M. Lucas for providing access to unpublished data sets. The Irminger Basin Iron Study (IBIS) was funded under NERC proposal NE/E005489/1 to E. Achterberg and C. M. Moore. MODIS Aqua data provided by NASA via the Ocean Colour website http://www.oceancolor.nasa.gov.

Edited by: K. Suzuki 


\section{References}

Achterberg, E. P., Moore, C. M., Henson, S. A., Steigenberger, S., Stohl, A., Eckhardt, S., Avendano, L. C., Cassidy, M., Hembury, D., Klar, J. K., Lucas, M. I., Macey, A. I., Marsay, C. M., and Ryan-Keogh, T. J.: Natural iron fertilization by the Eyjafjallajökull volcanic eruption, Geophys. Res. Lett., 40, 1-6, doi:10.1002/grl.50221, 2013.

Bacon, S., Reverdin, G., Rigor, I. G., and Snaith, H. M.: A freshwater jet on the east Greenland Shelf, J. Geophys. Res., 107, 3068, doi:10.1029/2001JC000935, 2002.

Bacon, S., Gould, W. J., and Jia, Y.: Open-ocean convection in the Irminger Sea, Geophys. Res. Lett., 30, 1246, doi:10.1029/2002GL016271, 2003.

Baker, A. R. and Croot, P. L.: Atmospheric and marine controls on aerosol iron solubility in seawater, Mar. Chem., 120, 4-13, 2010.

Baker, A. R., Weston, K., Kelly, S. D., Voss, M., Streu, P., and Cape, J. N.: Dry and wet deposition of nutrients from the tropical Atlantic atmosphere: links to primary productivity and nitrogen fixation, Deep-Sea Res. Pt. I, 54, 1704-1720, 2007.

Bhatia, M. P., Kujawinski, E. B., Das, S. B., Breier, C. F., Henderson, P. B., and Charette, M. A.: Greenland meltwater as a significant and potentially bioavailable source of iron to the ocean, Nat. Geosci., 6, 274-278, 2013.

Boyd, P. W., Muggli, D., Varela, D., Goldblatt, R. H., Chretien, R., Orians, K. J., and Harrison, P. J.: In vitro iron enrichment experiments in NE subarctic Pacific, Mar. Ecol.-Prog. Ser., 136, 179-193, 1996.

Boyd, P. W., Mackie, D. S., and Hunter, K. A.: Aerosol iron deposition to the surface ocean - modes of iron supply and biological response, Mar. Chem., 120, 128-143, 2009.

Croot, P. L., Frew, R. D., Sander, S., Hunter, K. A., Ellwood, M. J., Pickmere, S. E., Abraham, E. R., Law, C. S., Smith, M. J., and Boyd, P. W.: Physical mixing effects on iron biogeochemical cycling: FeCycle experiment, J. Geophys. Res., 112, C06015, doi:10.1029/2006JC003748, 2007.

de Boyer Montegut, C., Madec, G., Fischer, A. S., Lazar, A., and Ludicone, D.: Mixed layer depth over the global ocean: an examination of profile data and a profile-based climatology, J. Geophys. Res., 109, C12003, doi:10.1029/2004JC002378, 2004.

Donaghay, P. L., Liss, P. S., Duce, R. A., Kester, D. R., Hanson, A. K., Villareal, T., Tindale, N. W., and Gifford, D. J.: The role of episodic atmospheric nutrient inputs in the chemical and biological dynamics of oceanic ecosystems, Oceanography 4, 62-70, 1991.

Duce, R. A. and Tindale, N. W.: Atmospheric transport or iron and its deposition in the ocean, Limnol. Oceanogr., 36, 1715-1726, 1991.

Duce, R. A., LIss, P. S., Merrill, J. T., Atlas, E. L., Buat-Menard, P., Hicks, B. B., Miller, J. M., Prospero, J. M., Arimoto, R., Church, T. M., Ellis, W., Galloway, J. N., Hansen, L., Jickells, T. D., Knap, A. H., Reinhardt, K. H., Schneider, B., Soudine, A., Tokos, J. J., Tsunogai, S., Wollast, R., and Zhou, M.: The atmospheric input of trace species to the world ocean, Global Biogeochem. Cy., 5, 193-259, 1991.

Duggen, S., Olgun, N., Croot, P., Hoffmann, L., Dietze, H., Delmelle, P., and Teschner, C.: The role of airborne volcanic ash for the surface ocean biogeochemical iron-cycle: a review, Biogeosciences, 7, 827-844, doi:10.5194/bg-7-827-2010, 2010.
Elrod, V. A., Berelson, W. M., Coale, K. H., and Johnson, K. S.: The flux of iron from continental shelf sediments: a missing source for global budgets, Geophys. Res. Lett., 31, L12307, doi:10.1029/2004GL020216, 2004.

Eppley, R. W., Rogers, J. N., and McCarthy, J. J.: Half-saturation constants for uptake of nitrate and ammonium by marine phytoplankton, Limnol. Oceanogr., 14, 912-919, 1969.

Forryan, A., Martin, A. P., Srokosz, M. A., Popova, E. E., Painter, S. C., and Stinchcombe, M. C.: Turbulent nutrient fluxes in the Iceland Basin, Deep-Sea Res. Pt. I, 63, 20-35, 2012.

Ganzeveld, L., Lelieveld, J., and Roelofs, G.-J.: A dry deposition parameterization for sulfur oxides in a chemistry and general circulation model, J. Geophys. Res., 103, 5679-5694, 1998.

Han, Q., Moore, J. K., Zender, C., Measures, C., and Hydes, D.: Constraining oceanic dust deposition using surface ocean dissolved Al, Global Biogeochem. Cy., 22, GB2003, doi:10.1029/2007GB002975, 2008.

Harrison, P. J., Whitney, F. A., Tsuda, A., Saito, H., and Tadokoro, K.: Nutrient and plankton dynamics in the NE and NW gyres of the Subarctic Pacific Ocean, J. Oceanogr., 60, 93-117, 2004.

Henson, S. A., Sanders, R., Allen, J. T., Robinson, I. S., and Brown, L.: Seasonal constraints on the estimation of new production from space using temperature-nitrate relationships, Geophys. Res. Lett., 30, 1912, doi:10.1029/2003GL017982, 2003.

Henson, S. A., Sanders, R., Holeton, C., and Allen, J. T.: Timing of nutrient depletion, diatom dominance and a lower-boundary estimate of export production for Irminger Basin, North Atlantic, Mar. Ecol.-Prog. Ser., 313, 73-84, 2006.

Henson, S. A., Painter, S. C., Holliday, N. P., Stinchcombe, M. C., and Giering, S. L. C.: Unusual subpolar North Atlantic phytoplankton bloom in 2010: Volcanic fertilization or North Atlantic Oscillation? J. Geophys. Res., 118, 4771-4780, doi:4710.1002/jgrc.20363, 2013.

Ho, T.-Y., Quigg, A., Finkel, Z. V., Milligan, A. J., Wyman, K., Falkowski, P. G., and Morel, F. M. M.: The elemental composition of some marine phytoplankton, J. Phycol., 39, 1145-1159, 2003.

Holliday, N. P., Waniek, J. J., Davidson, R., Wilson, D., Brown, L., Sanders, R., Pollard, R. T., and Allen, J. T.: Large-scale physical controls on phytoplankton growth in the Irminger Sea Part I: Hydrographic zones, mixing and stratification, J. Marine Syst., 59, 201-218, 2006.

Hosoda, S., Ohira, T., Sato, K., and Suga, T.: Improved description of global mixed-layer depth using Argo profiling floats, J. Oceanogr., 66, 773-787, 2010.

Jickells, T. D., An, Z. S., Andersen, K. K., Baker, A. R., Bergametti, G., Brooks, N., Cao, J. J., Boyd, P. W., Duce, R. A., Hunter, K. A., Kawahata, H., Kubilay, N., LaRoche, J., Liss, P. S., Mahowald, N., Prospero, J. M., Ridgwell, A. J., Tegen, I., and Torres, R.: Global iron connections between desert dust, ocean biogeochemistry, and climate, Science, 308, 67-71, 2005.

Jickells, T. D., Liss, P. S., Broadgate, W., Turner, S., Kettle, A. J., Read, J., Baker, J., Cardenas, L. M., Carse, F., HamrenLarssen, M., Spokes, L., Steinke, M., Thompson, A., Watson, A., Archer, S. D., Bellerby, R. G. J., Law, C. S., Nightingale, P. D., Liddicoat, M. I., Widdicombe, C. E., Bowie, A., Gilpin, L. C., Moncoiffe, G., Savidge, G., Preston, T., Hadziabdic, P., Frost, T., Upstill-Goddard, R., Pedros-Alio, C., Simo, R., Jackson, A., 
Allen, A., and DeGrandpre, M. D.: A Lagrangian biogeochemical study of an eddy in the Northeast Atlantic, Prog. Oceanogr., 76, 366-398, 2008.

Johnson, K. S., Gordon, R. M., and Coale, K. H.: What controls dissolved iron concentrations in the world ocean?, Mar. Chem., 57, 137-161, 1997.

Kim, D.-O., Lee, K., Choi, S.-D., Kang, H.-S., Zhang, J.Z., and Chang, Y.-S.: Determination of diapycnal diffusion rates in the upper thermocline in the North Atlantic Ocean using sulfur hexafluoride, J. Geophys. Res., 110, C10010, doi:10.1029/2004JC002835, 2005.

Kirkwood, D. S.: Nutrients: Practical Notes on Their Determination in Seawater, ICES Techniques in Marine Environmental Sciences Report 17, International Council for the Exploration of the Seas, Copenhagen, 25 pp., 1996.

Koning, E., Gehlen, M., Flank, A.-M., Calas, G., and Epping, E.: Rapid post-mortem incorporation of aluminium in diatom frustules: evidence from chemical and structural analyses, Mar. Chem., 106, 208-222, 2007.

Lam, P. J. and Bishop, J. K. B.: The continental margin is a key source of iron to the HNLC North Pacific Ocean, Geophys. Res. Lett., 35, L07608, doi:107610.01029/02008GL033294, 2008.

Lam, P. J., Ohnemus, D. C., and Marcus, M. A.: The speciation or marine particulate iron adjacent to active and passive continental margins, Geochim. Cosmochim. Ac., 80, 108-124, 2012.

Law, C. S., Martin, A. P., Liddicoat, M. I., Watson, A. J., Richards, K. J., and Woodward, E. M. S.: A Lagrangrian SF 6 tracer study of an anticyclonic eddy in the North Atlantic: patch evolution, vertical mixing and nutrient supply to the mixed layer, Deep-Sea Res. Pt. II, 48, 705-724, 2001.

Ledwell, J. R., Watson, A. J., and Laws, C. S.: Mixing of a tracer in the pycnocline, J. Geophys. Res., 103, 21499-21529, 1998.

Ledwell, J. R., McGillicuddy Jr., D. J., and Anderson, L. A.: Nutrient flux into an intense deep chlorophyll layer in a mode-water eddy, Deep-Sea Res. Pt. II, 55, 1139-1160, 2008.

Lewis, M. R., Harrison, W. G., Oakey, N. S., Herbert, D., and Platt, T.: Vertical nitrate fluxes in the oligotrophic ocean, Science, 234, 870-873, 1986.

Louanchi, F. and Najjar, R. G.: Annual cycles of nutrients and oxygen in the upper layers of the North Atlantic Ocean, Deep-Sea Res. Pt. II, 48, 2155-2171, 2001.

Lucas, M., Seeyave, S., Sanders, R., Moore, C. M., Williamson, R., Stinchcombe, M.: Nitrogen uptake responses to a naturally Fefertilized phytoplankton bloom during the 2004/2005 CROZEX study, Deep-Sea Res. Pt. II, 54, 2138-2173, 2007.

Mahowald, N. M., Engelstaedter, S., Luo, C., Sealy, A., Artaxo, P., Benitez-Nelson, C., Bonnet, S., Chen, Y., Chuang, P. Y., Cohen, D. D., Dulac, F., Herut, B., Johansen, A. M., Kubilay, N., Losno, R., Maenhaut, W., Paytan, A., Prospero, J. M., Shank, L. M., and Siefert, R. L.: Atmospheric iron deposition: global distribution, variability, and human perturbations, Ann. Rev. Mar. Sci., 1, 245-278, doi:10.1146/annurev.marine.010908.163727, 2009.

Martin, A. P., Lucas, M. I., Painter, S. C., Pidcock, R., Prandke, H., Prandke, H., and Stinchcombe, M. C.: The supply of nutrients due to vertical turbulent mixing: a study at the Porcupine Abyssal Plain study site $\left(49^{\circ} 50^{\prime} \mathrm{N} 16^{\circ} 30^{\prime} \mathrm{W}\right)$ in the Northeast Atlantic, Deep-Sea Res. Pt. II, 57, 1293-1302, 2010.
Martin, J. H. and Fitzwater, S. E.: Iron deficiency limits phytoplankton growth in the northeast Pacific subarctic, Nature, 331, 341343, 1988.

Martin, J. H., Fitzwater, S. E., Gordon, R. M., Hunter, C. N., and Tanner, S. J.: Iron, primary production and carbon-nitrogen flux studies during the JGOFS North Atlantic Bloom experiment, Deep-Sea Res. Pt. II, 40, 115-134, 1993.

Measures, C. I. and Brown, E. T.: Estimating dust input to the Atlantic Ocean using surface water aluminium concentrations, in: The Impact of Desert Dust Across the Mediterranean, edited by: Guerzoni, S. and Chester, R., Kluwer Academic, 301-311, 1996.

Measures, C. I. and Vink, S.: On the use of dissolved aluminium in surface waters to estimate dust deposition to the ocean, Global Biogeochem. Cy., 14, 317-327, 2000.

Measures, C. I., Landing, W. M., Brown, M. T., and Buck, C. S.: High-resolution $\mathrm{Al}$ and $\mathrm{Fe}$ data from the Atlantic Ocean CLIVAR-CO $\mathrm{CO}_{2}$ Repeat Hydrography A16N transect: extensive linkages between atmospheric dust and upper ocean geochemistry, Global Biogeochem. Cy., 22, GB1005, doi:10.1029/2007GB003042, 2008.

Milne, A., Landing, W., Bizimis, M., and Mortona, P.: Determination of $\mathrm{Mn}, \mathrm{Fe}, \mathrm{Co}, \mathrm{Ni}, \mathrm{Cu}, \mathrm{Zn}, \mathrm{Cd}$ and $\mathrm{Pb}$ in seawater using high resolution magnetic sector inductively coupled mass spectrometry, Anal. Chim. Acta, 665, 200-207, 2010.

Moran, S. B. and Moore, R. M.: Evidence from mesocosm studies for biological removal of dissolved aluminium from seawater, Nature, 335, 706-708, 1988.

Morel, A., Huot, Y., Gentili, B., Werdell, P. J., Hooker, S. B., and Franz, B. A.: Examining the consistency of products derived from various ocean color sensors in open ocean (Case 1) waters in the perspective of a multi-sensor approach, Remote Sens. Environ., 111, 69-88, 2007.

Moum, J. N., Gregg, M., Lien, R., and Carr, M.: Comparison of turbulence kinetic-energy dissipation rate estimates from 2 ocean microstructure profilers, J. Atmos. Ocean Tech., 12, 346-366, 1995.

Nielsdottir, M. C., Moore, C. M., Sanders, R., Hinz, D. J., and Achterberg, E. P.: Iron limitation of the postbloom phytoplankton communities in the Iceland Basin, Global Biogeochem. Cy., 23, GB3001, doi:10.1029/2008GB003410, 2009.

Okin, G. S., Baker, A. R., Tegen, I., Mahowald, N. M., Dentener, F. J., Duce, R. A., Galloway, J. N., Hunter, K., Kanakidou, M., Kubilay, N., Prospero, J. M., Sarin, M., Surapipith, V., Uematsu, M., and Zhu, T.: Impacts of atmospheric nutrient deposition on marine productivity: roles of nitrogen, phosphorus, and iron, Global Biogeochem. Cy., 25, GB2022, doi:10.1029/2010GB003858, 2011.

Osborn, T. R.: Estimates of the local rate of vertical diffusion from dissipation measurements, J. Phys. Oceanogr., 10, 83-89, 1980.

Pickart, R. S., Straneo, F., and Moore, G. W. K.: Is Labrador Sea water formed in the Irminger Basin?, Deep-Sea Res. Pt. I, 50, 23-52, 2003.

Planquette, H., Statham, P. J., Fones, G. R., Charette, M. A., Moore, C. M., Salter, I., Nedelec, F. H., Taylor, S. L., French, M., Baker, A. R., Mahowald, N., and Jickells, T. D.: Dissolved iron in the vicinity of the Crozet Islands, Southern Ocean, Deep-Sea Res. Pt. II, 54, 1999-2019, 2007.

Poulton, A. J., Charalampopoulou, A., Young, J. R., Tarran, G. A., Lucas, M. I., and Quartly, G. D.: Coccolithophore dynamics in 
non-bloom conditions during late summer in the Iceland Basin (July-August 2007), Limnol. Oceanogr., 55, 1601-1613, 2010.

Raiswell, R. and Canfield, D. E.: The iron biogoechemical cycle past and present, Geochemical perspectives, 1, 1-220, 2012.

Redfield, A. C., Ketchum, B. H., and Richards, F. A.: The influence of organisms on the composition of sea-water, in: The Sea: Vol 2: Composition of Seawater Comparative and Descriptive Oceanography, edited by: Hill, M. N., Interscience, London, 2677, 1963.

Resing, J.A. and Measures, C.I.: Fluorometric determination of Al in seawater by flow injection analysis with in-line preconcentration. Analytical Chemistry 66, 4105-4111, 1994.

Rickli, J., Frank, M., Baker, A.R., Aciego, S., de Souza, G., Georg, R.B., and Halliday, A.N.: Hafnium and neodymium isotopes in surface waters of the eastern Atlantic Ocean: Implications for sources and inputs of trace metals to the ocean. Geochimica et Cosmochimica Acta 74, 540-557, 2010.

Rippeth, T., Simpson, J., Williams, E., and Inall, M.: Measurement of the rates of production and dissipation of turbulent kinetic energy in an energetic tidal flow: Red Wharf Bay revisited, J. Phys. Oceanogr., 33, 1889-1901, 2003.

Ryan-Keogh, T. J., Macey, A. I., Nielsdottir, M. C., Lucas, M. I., Steigenberger, S. S., Stinchcombe, M. C., Achterberg, E. P., Bibby, T. S., and Moore, C. M.: Spatial and temporal development of phytoplankton iron stress in relation to bloom dynamics in the high-latitude North Atlantic Ocean, Limnol. Oceanogr., 58, 533-545, 2013.

Saito, M. A., Noble, A. E., Tagliabue, A., Goepfert, T. J., Lamborg, C. H., and Jenkins, W. J.: Slow-spreading submarine ridges in the South Atlantic as a significant oceanic iron source, Nat. Geosci., 6, 775-779, 2013.

Sambrotto, R. N., Martin, J. H., Broenkow, W. W., Carlson, C., and Fitzwater, S. E.: Nitrate utilization in surface waters of the Iceland Basin during spring and summer of 1989, Deep-Sea Res. Pt. II, 40, 441-457, 1993.

Sanders, R., Brown, L., Henson, S., and Lucas, M.: New production in the Irminger Basin during 2002, J. Marine Syst., 55, 291-310, 2005.

Statham, P. J., Skidmore, M., and Tranter, M.: Inputs of glacially derived dissolved and colloidal iron to the coastal ocean and implications for primary production, Global Biogeochem. Cy., 22, GB3013, doi:3010.1029/2007GB003106, 2008.

Stefansson, U. and Olafsson, J.: Nutrients and fertility of Icelandic waters, Rit Fiskideildar, 12, 1-56, 1991.

Stips, A.: Dissipation measurements, in: Marine Turbulence: Theories, Observations and Models. Results of the CARTUM Project, edited by: Baumert, H., Simpson, J. and Sundermann, J., Cambridge University Press, Cambridge, 115-126, 2005.

Stoffyn, M.: Biological control of dissolved aluminium in seawater: experimental evidence, Science, 203, 651-653, 1979.
Strzepek, R. F., Maldonado, M. T., Higgins, J. L., Hall, J., Safi, K., Wilhelm, S. W., and Boyd, P. W.: Spinning the "Ferrous Wheel": the importance of the microbial community in an iron budget during the FeCycle experiment, Global Biogeochem. Cy., 19, GB4S26, doi:10.1029/2005GB002490, 2005.

Sunda, W. G. and Huntsman, S. A.: Iron uptake and growth limitation in oceanic and coastal phytoplankton, Mar. Chem., 50, 189-206, 1995.

Tagliabue, A., L. Bopp, J.-C. Dutay, A. R. Bowie, F. Chever, P. JeanBaptiste, E. Bucciarelli, D. Lannuzel, T. Remenyi, G. Sarthou, O. Aumont, M. Gehlen and C. Jeandel (2010). Hydrothermal contribution to the oceanic dissolved iron inventory. Nature Geoscience 3, 252-256.

Takeda, S.: Iron and phytoplankton growth in the subarctic North Pacific, Aqua-Bioscience Monographs, 4, 41-93, 2011.

Torres-Valdes, S., Tsubouchi, T., Bacon, S., Naveira-Garabato, A. C., Sanders, R., McLaughlin, F. A., Petrie, B., Kattner, G., Azetsu-Scott, K., and Whitledge, T. E.: Export of nutrients from the Arctic Ocean, J. Geophys. Res., 118, 1625-1644, doi:1610.1002/jgrc.20063, 2013.

Twining, B. S., Baines, S. B., Fisher, N. S., and Landry, M. R.: Cellular iron contents of plankton during the Southern Ocean Iron Experiment (SOFeX), Deep-Sea Res. Pt. I, 51, 1827-1850, 2004.

Waniek, J. J. and Holliday, N. P.: Large-scale physical controls on phytoplankton growth in the Irminger Sea, Part II: Model study of the physical and meteorological preconditioning, J. Marine Syst., 59, 219-237, 2006.

Waniek, J. J., Holliday, N. P., Davidosn, R., Brown, L., and Henson, S. A.: Freshwater control of onset and species composition of Greenland shelf spring bloom, Mar. Ecol.-Prog. Ser., 288, 45$57,2005$.

Watson, A. J.: Volcanic iron, $\mathrm{CO}_{2}$, ocean productivity and climate, Nature, 385, 587-588, 1997.

Watson, A. J.: Iron limitation in the oceans, in: The Biogeochemistry of Iron in Seawater, edited by: Turner, D. R. and Hunter, K. A., John Wiley and Sons Ltd, Chichester, 9-39, 2001.

Welschmeyer, N. A.: Fluorometric analysis of chlorophyll $a$ in the presence of chlorophyll $b$ and phaeopigments, Limnol. Oceanogr., 39, 1985-1992, 1994.

Wilkinson, D. and Bacon, S.: The spatial and temporal variability of the East Greenland Coastal Current from historic data, Geophys. Res. Lett., 32, L24618, doi:10.1029/2005GL024232, 2005.

Xie, P. and Arkin, P. A.: Global precipitation: a 17-year monthly analysis based on gauge observations, satellite estimates and numerical model outputs, B. Am. Meteorol. Soc., 78, 2539-2558, 1997.

Yamazaki, H. and Osborn, T.: Dissipation estimates for stratified turbulence, J. Geophys. Res., 95, 9739-9744, 1990.

Yashayaev, I., Bersch, M., and van Aken, H. M.: Spreading of the Labrador Sea Water to the Irminger and Iceland basins, Geophys. Res. Lett., 34, L10602, doi:10.1029/2006GL028999, 2007. 